\title{
N, P, and K Budgets and Changes in Selected Topsoil Nutrients over 10 Years in a Long-Term Experiment with Conventional and Organic Crop Rotations
}

\author{
Audun Korsaeth \\ Arable Crops Division, Norwegian Institute for Agricultural and Environmental Research, 2849 Kapp, Norway \\ Correspondence should be addressed to Audun Korsaeth, audun.korsaeth@bioforsk.no \\ Received 2 December 2011; Accepted 30 April 2012 \\ Academic Editor: Philip White \\ Copyright (C) 2012 Audun Korsaeth. This is an open access article distributed under the Creative Commons Attribution License, \\ which permits unrestricted use, distribution, and reproduction in any medium, provided the original work is properly cited.

\begin{abstract}
This study presents soil system budgets of N, P and K in six contrasting cropping systems during 10 years of a long-term experiment in southeast Norway. The experiment included systems with arable cash-cropping and with mixed arable-dairy cropping (cash- and fodder crops), with organic and conventional management represented in both groups. All major nutrient inputs and outputs were measured or estimated. State of the art conventional cash-cropping appeared to be balanced in terms of $\mathrm{N}$, whereas conventional mixed cropping had an $\mathrm{N}$ surplus. By contrast, less up to date conventional arable cash-cropping and all the organic systems showed indications of soil organic $\mathrm{N}$ depletion (negative $\mathrm{N}$ budgets). All the organic systems showed that mining of the soil $\mathrm{P}$ and $\mathrm{K}$ content occurs, whereas the conventional systems all had $\mathrm{P}$ and $\mathrm{K}$ surpluses. The results corresponded well with measured differences between systems in terms of ignition loss, $\mathrm{P}-\mathrm{AL}, \mathrm{K}-\mathrm{AL}$ and $\mathrm{K}-\mathrm{HNO}_{3}$ measured in 2009. This study shows that a fertile soil may be exposed to substantial mining of $\mathrm{N}, \mathrm{P}$ and $\mathrm{K}$ over many years before it is detectable by traditional analyses, and that field nutrient budgeting is a feasible, but data-demanding, approach to detect such misbalances at an early stage.
\end{abstract}

\section{Introduction}

In 1989, a large cropping system experiment, facilitated for measurements of runoff and leaching, was established at Apelsvoll in southeast Norway. Over the years, this experiment has provided data for many studies covering a range of different topics, including yields and yield quality (e.g., [1]), nutrient leaching and runoff losses (e.g., [2]), economic aspects (e.g., [3]), soil microbiology (e.g., [4]), soil physical and chemical properties (e.g., [5]), and the relation between food production and $\mathrm{N}$ losses [6].

Some major adjustments of the experimental design were made in 2000 [6]. In this overview, a synthesis of the results obtained after these changes are given for the major nutrient flows of $\mathrm{N}, \mathrm{P}$, and $\mathrm{K}$, with focus on changes in topsoil nutrient pools, as affected by misbalances between nutrient inputs and outputs at field level.
Numerous long-term experiments have shown that crop rotation and management affect soil fertility (e.g., [7-13]). However, considerable time is needed before identifiable changes in soil fertility emerge [14]. Nutrient budgets have been used widely in a range of farming systems to assess long-term sustainability (e.g., [15]), thus, supplementing soil measurements. In a discussion of uncertainties in nutrient budgets, Oenema et al. [16] distinguished between farm gate soil surface and soil system budgets. The latter accounts for nutrient inputs and outputs, recycling of nutrients within the system, nutrient loss pathways, and changes in soil nutrient pools. Soil system budgets were considered to possess the highest uncertainty of the three budgeting approaches, since nutrient losses via leaching, runoff, volatilization, and denitrification are classified as the most uncertain nutrient flows [17]. De Vries et al. [18], when estimating uncertainties in the soil system $\mathrm{N}$ budget of The Netherlands, reported 
that leaching to ground water and leaching to surface water had the highest relative uncertainty (coefficient of variation). Acquiring quality data on nutrient drainage and runoff may, therefore, considerably reduce the uncertainties of the soil system budget approach.

The present study is aimed at comparing the effects of management (i.e., organic versus nonorganic) and type of production (i.e., arable cash cropping versus mixed dairy farming) on their long-term sustainability in terms of plant nutrition, by a combination of soil system nutrient budgeting and soil measurements. Results on drainage discharge and water-borne nutrient losses will be presented in more detail elsewhere [19].

\section{Material and Methods}

2.1. Experimental Site and Treatments. In 1989, a 3.2 ha large experiment with pipe-drained plots was established at Apelsvoll Research Centre in central southeast Norway $\left(60^{\circ} 42^{\prime} \mathrm{N}, 10^{\circ} 51^{\prime} \mathrm{E}\right.$, altitude $\left.250 \mathrm{~m}\right)$. The climate of the region is humid continental with a mean annual precipitation of $600 \mathrm{~mm}$ and a mean annual temperature of $3.6^{\circ}$, and $12.0^{\circ} \mathrm{C}$ in the growing season (May to September). On the experimental area, which slopes 2-8\% northeast, deforestation was performed in 1935, whereafter it was used as pasture until 1975. During the following years, up to the establishment of the experiment in 1988, the field was cropped with a rotation including $10 \%$ root crops, $40 \%$ cereals, and 50\% ley, using an average of 10 tonnes cattle slurry ha $\mathrm{hr}^{-1}$ plus regular amounts of inorganic fertilizer. The first year after draining the experimental site (1989), the area was cropped with barley (Hordeum distichum L.). The major soil group of the experimental area is classified as Endostagnic Cambisol [20], with dominantly loam and silty sand textures. More detailed soil characteristics have been presented by Riley and Eltun [21], partly shown in Table 1.

The experimental site comprises 12 blocks $(30 \times 60 \mathrm{~m})$, separated by $7.5 \mathrm{~m}$ grass border zones (Figure 1). In each block, surface runoff is collected at the lower end and led to a sedimentation tank, and the blocks are separately drained with PVC pipes at a depth of $1 \mathrm{~m}$ with $7.5 \mathrm{~m}$ spacing. Surface runoff from the sedimentation tank and drainage water is transported in sealed plastic pipes to measuring stations equipped for discharge measurements (tipping buckets) and volume proportional sampling.

Using a randomised complete block design, six cropping systems, each with 2 replicates, were established on the twelve blocks in 1989. The first ten years (1989-1999) the experiment comprised three arable systems (conventional and integrated arable cropping without farmyard manure and organic cropping with some farmyard manure) and three mixed dairy systems (conventional, integrated, and organic production of both arable and forage crops, all with farmyard manure). Each block comprised eight $7.5 \times 30 \mathrm{~m}$ plots, on which all of the arable and/or fodder crops in the rotation were grown each year.

Some major adjustments of the experimental design were made in 2000 . The number of rotation plots was reduced

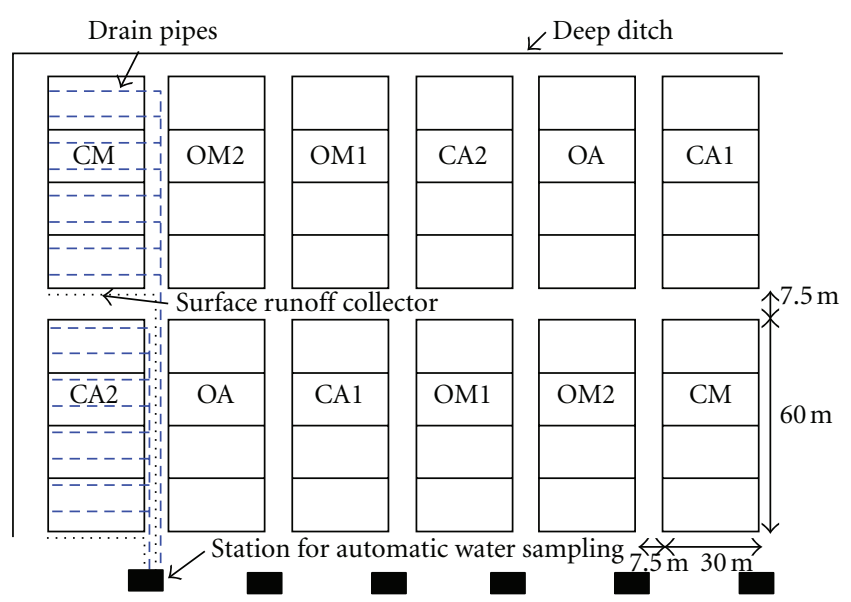

Figure 1: Layout of the cropping system experiment at Apelsvoll.

from eight to four by merging pairs of neighbouring plots, thus, reducing rotation length from eight to four years, but still with each crop present every year. A new organic mixed dairy system was introduced instead of the integrated mixed dairy system, and some smaller changes were made in the management of the other systems. The six adjusted cropping systems are described briefly below (see Table 2 for details).

CA1. Conventional arable cropping, managed as was common for the region in 1985 (tillage and fertilization as in 1985 , but for practical reasons, present-day inputs of seeds and chemical plant protection). The year 1985 was selected, since the North-Sea Agreement (1987) used this year as the base for its planned 50\% reduction in nutrient leaching to the North Sea within a 10-year period. Before this date, less attention was paid to nonpoint source losses of nutrients attributed to farming activities, and this cropping system is, thus, used as a reference.

CA2. Conventional arable cropping, using currently available knowledge in order to minimize the ratio of $\mathrm{N}$ lost by leaching and runoff to production. This optimisation involves the use of catch crops, split application of fertilizer, and reduced noninversion tillage.

$O A$. Organic arable cropping without cattle slurry, but with $25 \%$ of the area used for green manure (grass clover ley).

CM. Conventional mixed dairy farming, optimised similarly to CA2, but with spring ploughing, $50 \%$ of the area as grass clover ley and the use of slurry (amounts calculated from the theoretical number of cows sustained, see Section 2.3 for details).

OM1. Organic mixed dairy farming with $50 \%$ of the area as grass clover ley and slurry use (amounts calculated as in CM).

OM2. Organic mixed dairy farming with $75 \%$ of the area as grass clover ley and slurry use (amounts calculated as in CM). 
TABLE 1: Mean values of selected soil physical parameters in topsoil $(0-30 \mathrm{~cm})$ measured in 1988, prior to the start of the experiment (from $[21])$.

\begin{tabular}{|c|c|c|c|c|c|c|c|c|c|c|}
\hline \multirow{2}{*}{ System } & \multicolumn{10}{|c|}{ Parameter number ${ }^{1}$} \\
\hline & 1 & 2 & 3 & 4 & 5 & 6 & 7 & 8 & 9 & 10 \\
\hline CA1 & 51 & 10 & 11 & 29 & 12 & 7 & 6 & 43 & 38 & 19 \\
\hline CA2 & 48 & 10 & 6 & 27 & 11 & 3 & 9 & 52 & 33 & 15 \\
\hline OA & 49 & 7 & 7 & 30 & 12 & 4 & 6 & 46 & 35 & 19 \\
\hline $\mathrm{CM}$ & 48 & 9 & 8 & 27 & 12 & 5 & 9 & 47 & 35 & 19 \\
\hline OM1 & 49 & 7 & 9 & 30 & 12 & 6 & 8 & 50 & 33 & 17 \\
\hline OM2 & 50 & 8 & 7 & 30 & 12 & 4 & 5 & 45 & 36 & 19 \\
\hline s.e. $^{2}$ & 1.5 & 1.2 & 2.5 & 1.2 & 0.5 & 2.1 & 1.5 & 1.5 & 1.0 & 1.0 \\
\hline Mean & 49 & 9 & 8 & 29 & 12 & 5 & 7 & 47 & 35 & 18 \\
\hline
\end{tabular}

${ }^{1}$ Parameter number: (1) total porosity (\%), (2) air capacity at pF2 (\%), (3) air permeability at pF2 ( $\left.\mu \mathrm{m}^{2}\right),(4)$ total available water (pF 2-4.2) (\%), (5) nonavailable water $(\mathrm{pF}>4.2)(\%),(6)$ hydraulic conductivity $(\mathrm{cm} / \mathrm{h}),(7)$ gravel content $(\%),(8)$ sand content $(\%),(9)$ silt content $(\%),(10)$ clay content $(\%)$.

${ }^{2}$ Standard error of means.

The results in 2000 were partly influenced by the previous management. Therefore, this paper deals with the results from the decade May 2001-April 2011.

2.2. Measurements. Within each plot, dry matter (DM) yields of grass, grain, straw (when removed), and potato tubers were measured in quadruplicate (subplot size $1.5 \times$ $6 \mathrm{~m})$. Straw was removed from all the cereal plots of CA1 and from the plots with barley undersown with grass clover ley in OA, CM, OM1, and OM2. Crude protein contents of the cereals were measured by near infrared reflectometry (INFRA 250, Technicon, USA). Potato tuber size distribution and quality parameters were determined according to standard procedures. The proportion of legumes in the grass clover ley was determined visually before harvest.

From 2006 onwards, plant samples of all harvested crops $(0.2 \mathrm{~g} \mathrm{DM})$ were digested in a mixture of sulfuric acid and hydrogen peroxide and analysed for $\mathrm{N}$ and $\mathrm{P}$ colorimetrically with an autoanalyser (Skalar 5100, Actlabs, Canada) and for K by flame photometry (Corning 400, Sherwood Scientific Ltd., UK).

Cattle slurry was sampled 1-2 weeks before application and analysed for total- $\mathrm{N}$ using the Kjeldahl method. Ammonium- $\mathrm{N}$ and nitrate- $\mathrm{N}$ were extracted with $2 \mathrm{M}$ $\mathrm{KCl}$ and determined colorimetrically with an autoanalyser (Traacs, Bran and Luebbe, Germany).

The water samples (drainage water and surface runoff) were analysed on a monthly basis for total $\mathrm{N}$, ammonium- $\mathrm{N}$, nitrate- $\mathrm{N}$, total $\mathrm{P}$, phosphate $\mathrm{P}$, and total $\mathrm{K}$ and determined spectrophotometrically (DR2800 spectrophotometer, Hach Lange, Germany). Potassium was first included in May 2009.

Soil samples have been taken every 3-5 years since 1989. Due to differences in sampling depths, sampling locations, and parameters analysed, only selected samples are comparable. In this study results are shown for topsoil samples (0-25 cm depth) taken in 1996, 1999, 2003, and 2009. The samples taken in 1999 and 2009 were analysed for ignition loss (at $550^{\circ} \mathrm{C}$ ), whereas samples taken in 1996, 2003, and 2009 were used to quantify plant available P and K and acid soluble K. Plant available P (P-AL) and K (K-AL) was extracted by a mixture of acetic acid and ammonium lactate, according to Egnér et al. [22], whereas acid soluble $\mathrm{K}\left(\mathrm{K}-\mathrm{HNO}_{3}\right)$ was extracted by boiling in $1 \mathrm{M} \mathrm{HNO}_{3}$. The $\mathrm{P}$ and $\mathrm{K}$ concentrations in the extracts were analysed by inductively coupled plasma (ICP) techniques (SPECTRO GENESIS, Analytical Instruments GmbH, Germany).

2.3. Calculations and Estimates. Dry and wet atmospheric $\mathrm{N}$ deposition was set to 2.7 and $7.2 \mathrm{~kg} \mathrm{~N} \mathrm{ha}^{-1} \mathrm{yr}^{-1}$, respectively, and wet atmospheric $\mathrm{K}$ deposition was set to $2.1 \mathrm{~kg} \mathrm{ha}^{-1} \mathrm{yr}^{-1}$, based on measurements at the nearest monitoring station, Hurdal [23], about $50 \mathrm{~km}$ south of Apelsvoll. Dry depositions of $\mathrm{K}$ and wet and dry $\mathrm{P}$ depositions were assumed to be negligible.

Symbiotic $\mathrm{N}$ fixation was estimated in accordance with Korsaeth and Eltun [2]. Nonsymbiotic $\mathrm{N}$ fixation was considered to be negligible. Nutrient inputs with seeds were estimated using measured $\mathrm{N}, \mathrm{P}$, and $\mathrm{K}$ contents of harvested grain and potatoes from the CON-A system. Literature values were selected for legumes and grasses.

The amounts of $\mathrm{N}$ in cattle slurry applied were calculated as the sum of $\mathrm{N}$ in harvested forage (grass clover ley) and feed concentrates (purchased and/or produced on the farm), minus the estimated $\mathrm{N}$ losses occurring from harvest until slurry application (forage losses, gaseous losses from the cow shed, and during slurry storage) and $\mathrm{N}$ exports via milk and livestock, as described in detail by Korsaeth [6]. The number of cows which each farming system could sustain was calculated from the average total available feed in the system during the previous three years (sliding mean) and the feed requirement for milk production, maintenance, activity and replacement. On the conventional farm, it was assumed that purchased cereal-based feed concentrates corresponded to $25 \%$ of the total fodder units available (feed concentrates plus forage grass). The organic systems were assumed to be completely self-sufficient, using on-farm produced barley as feed concentrates, for at most $20 \%$ of the 
TABle 2: Characteristics of the cropping systems at Apelsvoll, 2001-2010.

\begin{tabular}{|c|c|c|c|c|c|c|c|c|}
\hline \multirow{2}{*}{ Crop rotation } & \multicolumn{3}{|c|}{ Fertilizer, $\mathrm{kg} \mathrm{ha}^{-1}$} & \multicolumn{3}{|c|}{ Slurry, kg ha ${ }^{-1}$} & \multirow{2}{*}{ Plant protection } & \multirow{2}{*}{ Soil tillage } \\
\hline & $\mathrm{N}$ & $\mathrm{P}$ & $\mathrm{K}$ & $\mathrm{N}$ & $\mathrm{P}$ & $\mathrm{K}$ & & \\
\hline \multicolumn{9}{|c|}{ Conventional arable $(\mathrm{CA} 1)^{1}$} \\
\hline Potatoes & 119 & 51 & 183 & & & & Chemical, mechanical & \multirow{4}{*}{$\begin{array}{l}\text { Autumn ploughing } \\
\text { and spring harrowing }\end{array}$} \\
\hline Spring wheat & 141 & 25 & 66 & & & & Chemical & \\
\hline Spring oats & 120 & 22 & 57 & & & & Chemical & \\
\hline Spring barley & 120 & 22 & 57 & & & & Chemical & \\
\hline \multicolumn{9}{|c|}{ Conventional arable (CA2) } \\
\hline Potatoes & $108^{2}$ & 47 & 164 & & & & Chemical, mech. & \multirow{4}{*}{$\begin{array}{l}\text { Spring harrowing } \\
\text { only }^{7}\end{array}$} \\
\hline Wheat + catch crop $^{3}$ & $134^{2,4}$ & 29 & 80 & & & & Chemical, mech. ${ }^{5}$ & \\
\hline Oats + catch crop ${ }^{6}$ & $116^{2}$ & 21 & 55 & & & & Chemical, mech. ${ }^{5}$ & \\
\hline Barley + catch crop $^{3}$ & $116^{2}$ & 21 & 55 & & & & Chemical, mech. ${ }^{5}$ & \\
\hline \multicolumn{9}{|c|}{ Organic arable (OA) } \\
\hline Barley $^{8}$ & & & & & & & Manual weeding & \multirow{4}{*}{$\begin{array}{l}\text { Spring ploughing and } \\
\text { harrowing }\end{array}$} \\
\hline Grass clover ${ }^{9}$ & & & & & & & Manual w. & \\
\hline S. wheat + catch crop & & & & & & & Manual w., mech. 5,10 & \\
\hline Oats + peas & & & & & & & Manual w., mech. ${ }^{10}$ & \\
\hline \multicolumn{9}{|c|}{ Conventional mixed dairy farming $(\mathrm{CM})$} \\
\hline Barley $^{11}$ & $50^{2}$ & 9 & 24 & 70 & 10 & 90 & Chemical & \multirow{4}{*}{$\begin{array}{l}\text { Spring ploughing and } \\
\text { harrowing }\end{array}$} \\
\hline 1st ley year & $99^{2}$ & 16 & 75 & 57 & 8 & 73 & - & \\
\hline 2nd ley year & $114^{2}$ & 19 & 86 & 80 & 11 & 104 & - & \\
\hline S. wheat + catch crop & $86^{2,4}$ & 16 & 43 & 69 & 10 & 90 & Chemical, mech. ${ }^{5}$ & \\
\hline \multicolumn{9}{|c|}{ Organic mixed dairy farming (OM1) } \\
\hline Barley $^{11}$ & & & & 75 & 11 & 98 & Manual w. & \multirow{4}{*}{$\begin{array}{l}\text { Spring ploughing and } \\
\text { harrowing }\end{array}$} \\
\hline 1st ley year & & & & 24 & 2 & 31 & Manual w. & \\
\hline 2nd ley year & & & & 48 & 6 & 63 & Manual w. & \\
\hline S. wheat + catch crop & & & & 83 & 12 & 107 & Manual w., mech.., 10 & \\
\hline \multicolumn{9}{|c|}{ Organic mixed dairy farming (OM2) } \\
\hline Barley $^{11}$ & & & & 93 & 13 & 112 & Manual w. & \multirow{4}{*}{$\begin{array}{l}\text { Spring ploughing and } \\
\text { harrowing }\end{array}$} \\
\hline 1st ley year & & & & 63 & 8 & 80 & Manual w. & \\
\hline 2nd ley year & & & & 98 & 13 & 122 & Manual w. & \\
\hline 3rd ley year & & & & 75 & 10 & 93 & Manual w. & \\
\hline
\end{tabular}

${ }^{1}$ Managed as was common for the region in 1985 (tillage and fertilization as in 1985, but for practical reasons, present-day inputs of seeds and chemical plant protection).

${ }^{2}$ Fertilizer level in spring adjusted according to regional recommendations, based on measurements of mineral $\mathrm{N}$ in topsoil in early spring. Average values are shown.

${ }^{3}$ Perennial ryegrass (Lolium perenne L), sown about one week after the cereals.

${ }^{4}$ Split application of fertilizer with about $75 \%$ given at sowing, and $0-60 \mathrm{~kg} \mathrm{~N}$ ha $^{-1}$ applied at growth stage (GS) 49 , according to measurements with the N tester [6].

${ }^{5}$ Weed harrowing performed when the cereals are at GS 11-12.

${ }^{6}$ Italian ryegrass (Lolium multiflorum Lam), sown about one week after the oats.

${ }^{7}$ Performed twice with a horizontally rotating harrow.

${ }^{8}$ With undersown grass-clover mixture. Seed mix: 80\% Timothy (Phleum pratense L.), 10\% red clover (Trifolium pratense L.), and 10\% white clover (Trifolium repens $\mathrm{L}$ ).

${ }^{9}$ Green manure, not harvested but mulched 3-4 times per season.

${ }^{10}$ Harrowed in autumn after harvest some years to reduce the weed pressure.

${ }^{11}$ With undersown grass-clover ley. Seed mix: 60\% Timothy (Phleum pratense L.), 30\% Meadow fescue (Festuca pratensis L.), and 10\% red clover (Trifolium pratense L.). 
total feed requirement. Barley not used as concentrates was assumed to be sold.

The yearly average cereal yields of OA were reduced by $25 \%$ to correct for the area used for green manure production. In 2007, the mixture of oat and peas in OA was replaced in the rotation by faba bean (Vicia faba L.). These beans were totally damaged by chocolate spot (Ascochyta blight disease) and not harvested. All OA data from 2007 were, thus, excluded from further analyses.

Nutrient concentrations ( $\mathrm{N}, \mathrm{P}$, and $\mathrm{K}$ ) in harvested products (crops and straw) for the years 2001-2005 were set equal to the averages (separately for each cropping system) for the years 2006-2010. Removal of N, P, and $\mathrm{K}$ was calculated as the measured dry weight of products removed from the field multiplied by the estimated nutrient concentrations. Amounts of N, P and $\mathrm{K}$ in harvested grass were reduced by $10 \%$ to correct for likely losses under practical harvest.

Gaseous N-emissions $\left(\mathrm{N}_{2} \mathrm{O}-\mathrm{N}, \mathrm{NO}_{x}-\mathrm{N}\right.$, and $\left.\mathrm{NH}_{3}-\mathrm{N}\right)$ were estimated from the IPCC framework [24], which comprises estimates for both direct and indirect emissions. Nitrogen sources included in the direct estimates used here were mineral $\mathrm{N}$ fertilizer, applied $\mathrm{N}$ in slurry, and $\mathrm{N}$ in above-ground and below-ground crop residues. Net $\mathrm{N}$ mineralization associated with possible loss of SOM resulting from contrasting management was not considered. The volatilization of $\mathrm{NH}_{3}-\mathrm{N}$ (and $\mathrm{NO}_{x}-\mathrm{N}$ ) is in the IPCC framework [24] related to the input of mineral fertilizer and organic $\mathrm{N}$ additions, not including crop residues. This implies that the mulched grass clover in OA would have zero emissions of $\mathrm{NH}_{3}-\mathrm{N}$ using the IPCC-approach, which is very unrealistic (e.g., [25]). Hence, the volatilization of $\mathrm{NH}_{3}-\mathrm{N}$ from this crop was calculated by means of a separate method [6].

Nutrient runoff occurring during each agrohydrological year, lasting from 1 May to 30 April, was attributed to the cropping season within that period. Calculations of N, P, and $\mathrm{K}$ transported via surface runoff and drainage water were based on measured nutrient concentrations and volumes of surface and drainage water. Organic N was calculated as the difference between total $\mathrm{N}$ and the sum of ammonium$\mathrm{N}$ and nitrate- $\mathrm{N}$. Potassium runoff occurring during the agrohydrological years 2001-2008 were set equal to the measured average $\mathrm{K}$ runoff for the agrohydrological years 2009/10 and 2010/11.

Nutrient soil system budgets were calculated separately for each system by considering all major flows of $\mathrm{N}, \mathrm{P}$, and $\mathrm{K}$, respectively, with the above-ground crops representing the upper boundary and the drain pipes the lower boundary. A positive soil system budget, that is, where the inputs exceeded the outputs, was taken as an indication of nutrient accumulation, whereas a negative budget was taken as an indication of soil mining of the nutrient in question.

2.4. Statistics. Analyses of variance (ANOVA) were performed on yields and nutrient concentrations, using a splitplot model with cropping system as main plot and year as subplot. Grass-clover ley yields were analysed as the sum of two cuts, whereas differences in nutrient concentrations were analysed for each cut separately. Paired comparisons (LSD) were performed [26]. Comparisons of soil chemical properties measured on different occasions were conducted using the paired Student's $t$-test. In all tests, significance was assumed at $P$ levels $<0.05$. Mean data are presented with their standard errors (s.e.).

\section{Results}

3.1. Yields. There were significant yield differences between cereal crops within each group of cropping systems (Table 3 ). The conventional arable systems (CA1 and CA2) gave the largest overall cereal yields; the conventional mixed dairy system (CM) was intermediate, whereas the organic systems gave the lowest yields. The organic arable system had the lowest (area corrected) yields overall, achieving only 40 and $44 \%$, respectively, of the barley and wheat harvested in the arable conventional systems. The mixture of oats and peas in OA compared slightly more favourably, but still with only $47 \%$ of the yield level obtained with monocropped oats in CA1 and CA2 (Table 3).

The total fresh weight yield of potatoes was $43 \pm$ $1.3 \mathrm{Mgha}^{-1}$, and there was no significant difference in yield (Table 3), size distribution, or selected quality parameters between the two cropping systems with potatoes in the rotation (CA1 and CA2, data not shown). The DM content was $0.224 \pm 0.005 \mathrm{~kg} \mathrm{DM} \mathrm{kg}$ fresh weight ${ }^{-1}$, and about $93 \%$ (weight basis) of the potato tubers were saleable.

The conventional mixed dairy system (CM) had significantly larger grass clover ley yields than the organic systems, both for the 1st and the 2nd ley years (Table 4 ). There was no significant yield difference between the organic systems. Their total production in the two first ley years was $86 \%$ of that obtained conventionally.

The annual DM yield of the systems averaged over crops appeared to follow the same pattern between years within each production group (Figure 2).

3.2. Nutrient Concentrations of the Harvested Crops. The only differences in nutrient concentrations among the cash crops were for barley $\mathrm{N}$ and $\mathrm{K}$ (Table 3 ). The barley $\mathrm{N}$ concentration was highest in CA1, followed by CA2 and OM2 whereas OA had the lowest $\mathrm{N}$ concentration. The differences were smaller for $\mathrm{K}$, with highest concentration in barley from $\mathrm{OM} 2$, and lowest in barley from CA2 and CM.

The $\mathrm{N}$ concentration in herbage (grass clover ley) differed significantly between systems at the 2nd cut in both ley year 1 and 2 (ley year 3 was not comparable between systems), with lower concentration in $\mathrm{CM}$ than in the two organic systems, which had similar concentrations (Table 4). For the concentrations of $\mathrm{K}$, the tendency was opposite, at least at the first cut. Organically cropped grass clover ley had significantly lower $\mathrm{K}$ concentration than that of $\mathrm{CM}$ at the first cut of ley year 2. 
TABLE 3: Harvested yields of cereals and potatoes and their concentrations of N, P, and K.

\begin{tabular}{|c|c|c|c|c|c|c|c|c|c|c|c|c|c|}
\hline \multirow{3}{*}{ Crop } & \multirow{3}{*}{ System } & & & \multirow[b]{3}{*}{$c^{3}$} & \multicolumn{9}{|c|}{ Nutrient concentrations (g $100 \mathrm{~g} \mathrm{DM}^{-1}$ ) } \\
\hline & & \multirow{2}{*}{\multicolumn{2}{|c|}{$\underset{\text { Mean }}{\text { Yield }^{1}} \underset{\text { S.e. }^{2}}{\left(\mathrm{~kg} \mathrm{ha}^{-1}\right)}$}} & & \multicolumn{3}{|c|}{$\mathrm{N}$} & \multicolumn{3}{|c|}{$\mathrm{P}$} & \multicolumn{3}{|c|}{$\mathrm{K}$} \\
\hline & & & & & Mean & s.e. & $\mathrm{C}$ & Mean & s.e. & $\mathrm{c}$ & Mean & s.e. & $\mathrm{C}$ \\
\hline \multirow{7}{*}{ Barley } & CA1 & 5450 & 152 & $\mathrm{a}$ & 2.05 & 0.061 & $\mathrm{a}$ & 0.40 & 0.025 & & 0.39 & 0.008 & $a b$ \\
\hline & CA2 & 5181 & 148 & $\mathrm{ab}$ & 1.99 & 0.054 & $\mathrm{ab}$ & 0.40 & 0.027 & & 0.37 & 0.006 & $\mathrm{~b}$ \\
\hline & OA & 2148 & 125 & d & 1.68 & 0.034 & c & 0.41 & 0.015 & & 0.39 & 0.009 & $\mathrm{ab}$ \\
\hline & $\mathrm{CM}$ & 4865 & 134 & $\mathrm{~b}$ & 1.85 & 0.034 & $\mathrm{bc}$ & 0.39 & 0.019 & & 0.37 & 0.006 & $\mathrm{~b}$ \\
\hline & OM1 & 3881 & 130 & c & 1.77 & 0.035 & $\mathrm{bc}$ & 0.40 & 0.019 & & 0.40 & 0.003 & $a b$ \\
\hline & OM2 & 4017 & 153 & c & 1.94 & 0.042 & $\mathrm{ab}$ & 0.42 & 0.020 & & 0.41 & 0.006 & $\mathrm{a}$ \\
\hline & LSD & 347 & & & 0.18 & & & n.s. & & & 0.02 & & \\
\hline \multirow{4}{*}{ Oats } & CA1 & 5866 & 260 & $\mathrm{a}$ & 2.07 & 0.050 & & 0.38 & 0.020 & & 0.37 & 0.006 & \\
\hline & CA2 & 5264 & 214 & $\mathrm{a}$ & 1.99 & 0.059 & & 0.39 & 0.012 & & 0.39 & 0.007 & \\
\hline & $\mathrm{OA}^{4}$ & 2618 & 297 & $\mathrm{~b}$ & 2.30 & 0.155 & & 0.43 & 0.012 & & 0.59 & 0.012 & \\
\hline & LSD & 944 & & & n.s. & & & n.s. & & & n.s. & & \\
\hline \multirow{6}{*}{ Wheat } & CA1 & 5696 & 217 & $\mathrm{a}$ & 2.25 & 0.047 & & 0.40 & 0.023 & & 0.40 & 0.002 & \\
\hline & CA2 & 5606 & 252 & $\mathrm{a}$ & 2.30 & 0.037 & & 0.41 & 0.018 & & 0.39 & 0.008 & \\
\hline & OA & 2494 & 185 & d & 2.23 & 0.070 & & 0.45 & 0.012 & & 0.39 & 0.007 & \\
\hline & $\mathrm{CM}$ & 4900 & 260 & $\mathrm{~b}$ & 2.34 & 0.044 & & 0.42 & 0.014 & & 0.39 & 0.005 & \\
\hline & OM1 & 3719 & 187 & c & 2.21 & 0.078 & & 0.42 & 0.013 & & 0.39 & 0.009 & \\
\hline & LSD & 574 & & & n.s. & & & n.s. & & & n.s. & & \\
\hline \multirow{3}{*}{ Potatoes } & CA1 & 9474 & 328 & & 1.20 & 0.016 & & 0.30 & 0.004 & & 1.45 & 0.047 & \\
\hline & CA2 & 9535 & 349 & & 1.22 & 0.038 & & 0.28 & 0.001 & & 1.42 & 0.058 & \\
\hline & LSD & n.s. & & & n.s. & & & n.s. & & & n.s. & & \\
\hline
\end{tabular}

${ }^{1}$ Yields of cereals were corrected to a water content of 15\%, whereas yields of potatoes are presented as DM.

${ }^{2}$ Standard error of means. Yield data were averaged for the years 2001-2010, whereas data on nutrient concentrations were averaged for the years 2006-2010. ${ }^{3}$ Pairwise comparisons of yields/nutrient concentrations using LSD at the $5 \%$ level, where yields/nutrient concentration of the same crop differing significantly between systems are denoted different letters. Nonsignificant comparisons are denoted n.s.

${ }^{4}$ In the organic system OA, oat was grown in a mixture with peas. Yields are given as the sum of the two crops, whereas nutrient concentrations are given as a weighted average (based on the DM weights of the two crops).

\subsection{Soil System Nutrient Budgets}

3.3.1. Nitrogen. The $\mathrm{N}$ input was in the range of $60-112 \%$ of the $\mathrm{N}$ output (Table 5). The arable system CA1 and all the organic systems had negative soil system $\mathrm{N}$ budgets, indicating depletion of the soil organic $\mathrm{N}$ content. Over the 10 years, the reductions amounted to $280,319,225$, and $114 \mathrm{~kg} \mathrm{~N} \mathrm{ha}^{-1}$ for CA1, OA, OM1, and OM2, respectively. By contrast, the budget of CA2 appeared to be balanced, whereas $\mathrm{CM}$ had an $\mathrm{N}$ surplus amounting to $198 \mathrm{~kg} \mathrm{~N} \mathrm{ha}^{-1}$.

The annual soil system $\mathrm{N}$ budgets (and those for $\mathrm{P}$ and $\mathrm{K})$ were rather consistent over years for the arable systems, whereas the annual budgets of the mixed dairy systems appeared to be more positive in 2001 and 2002 than during the rest of the decade (Figure 2).

The amount of $\mathrm{N}$ in harvested cereals and potatoes of CA 1 and CA 2 corresponded to 83 and $84 \%$ of that applied, respectively (Table 5 ). The proportion was somewhat lower in the mixed dairy system CM (73\%), whereas in the organic systems OM1 and OM2 the $\mathrm{N}$ removal exceeded that applied by 54 and $86 \%$, respectively.

When comparing the sum of $\mathrm{N}$ lost via drainage and runoff with that applied (in fertilizer and/or cattle slurry),
CA1 had the largest quotient within the arable cropping system group, and, correspondingly, OM1 had the largest quotient within the group of mixed dairy systems (Table 5).

The arable systems had the largest losses of $\mathrm{N}$ (via drainage and runoff) per unit of harvested $\mathrm{N}$ (loss-to-harvest ratio), with $\mathrm{OA}$ having the overall largest loss-to-harvest ratio (Table 5 ). The water based $\mathrm{N}$ losses from this system corresponded to $67 \%$ of the $\mathrm{N}$ in harvested products. By contrast, CA2 lost only amounts corresponding to $27 \%$ of the harvested $\mathrm{N}$. The differences were much smaller within the group of mixed dairy systems, with $\mathrm{N}$ losses ranging from $13-24 \%$ of the harvested $\mathrm{N}$.

3.3.2. Phosphorus. The $\mathrm{P}$ input was in the range of $8-156 \%$ of the P output (Table 6 ). The P budgets differed markedly between organic and conventionally managed systems. All three organic systems showed depletions of the soil $\mathrm{P}$ content amounting to 82,100 , and $98 \mathrm{~kg} \mathrm{Pha}^{-1}$ for OA, OM1, and $\mathrm{OM} 2$, respectively. The conventional systems all had a calculated $\mathrm{P}$ surplus, particularly CA1 and CA2, which appeared to accumulate $\mathrm{P}$ in the same order of magnitude as the $\mathrm{P}$ reductions in the organic systems. 
TABLE 4: Harvested ley yields, clover contentand concentrations of N, P, and K.

\begin{tabular}{|c|c|c|c|c|c|c|c|c|c|c|c|c|c|c|c|c|}
\hline \multirow{3}{*}{ Year } & \multirow{3}{*}{$\begin{array}{l}\text { System } \\
\text { Cut }\end{array}$} & & & & & & \multirow[b]{3}{*}{$c^{4}$} & \multicolumn{9}{|c|}{ Nutrient concentrations (g $100 \mathrm{~g} \mathrm{DM}^{-1}$ ) } \\
\hline & & \multicolumn{3}{|c|}{ Yield (kg DM ha-1) } & \multicolumn{2}{|c|}{ Clover $^{1}(\%)$} & & \multicolumn{3}{|c|}{$\mathrm{N}$} & \multicolumn{3}{|c|}{$\mathrm{P}$} & \multicolumn{3}{|c|}{$\mathrm{K}$} \\
\hline & & Mean & s.e. $^{2}$ & $c^{3}$ & Mean & s.e. & & Mean & s.e. & $c^{5}$ & Mean & s.e. & c & Mean & s.e. & c \\
\hline \multirow{11}{*}{ Yr 1} & $\mathrm{CM}$ & 9630 & 335 & $\mathrm{a}$ & & & & & & & & & & & & \\
\hline & Cut 1 & 4765 & 171 & & 7 & 1.4 & $\mathrm{~b}$ & 1.50 & 0.06 & & 0.22 & 0.01 & & 1.84 & 0.09 & \\
\hline & Cut 2 & 4865 & 243 & & 10 & 2.4 & B & 1.48 & 0.09 & B & 0.28 & 0.02 & & 1.98 & 0.14 & \\
\hline & OM1 & 8203 & 319 & $\mathrm{~b}$ & & & & & & & & & & & & \\
\hline & Cut 1 & 4092 & 218 & & 27 & 2.6 & $\mathrm{a}$ & 1.55 & 0.09 & & 0.22 & 0.01 & & 1.69 & 0.06 & \\
\hline & Cut 2 & 4111 & 248 & & 45 & 4.7 & A & 2.24 & 0.05 & A & 0.31 & 0.02 & & 2.10 & 0.10 & \\
\hline & OM2 & 8342 & 278 & $\mathrm{~b}$ & & & & & & & & & & & & \\
\hline & Cut 1 & 4099 & 194 & & 27 & 2.4 & $\mathrm{a}$ & 1.61 & 0.10 & & 0.24 & 0.016 & & 1.68 & 0.11 & \\
\hline & Cut 2 & 4243 & 228 & & 40 & 5.0 & A & 2.16 & 0.16 & A & 0.32 & 0.01 & & 2.02 & 0.08 & \\
\hline & $\mathrm{LSD}^{6}$ & 710 & & & 12 & & & n.s. & & & n.s. & & & n.s. & & \\
\hline & $\mathrm{LSD}^{7}$ & & & & 11 & & & 0.45 & & & n.s. & & & n.s. & & \\
\hline \multirow{11}{*}{ Yr 2} & $\mathrm{CM}$ & 11021 & 304 & $\mathrm{a}$ & & & & & & & & & & & & \\
\hline & Cut 1 & 6269 & 180 & & 11 & 2.1 & $\mathrm{~b}$ & 1.57 & 0.04 & & 0.24 & 0.01 & & 1.99 & 0.08 & $\mathrm{a}$ \\
\hline & Cut 2 & 4752 & 233 & & 11 & 2.1 & A & 1.46 & 0.06 & B & 0.27 & 0.02 & & 1.82 & 0.09 & \\
\hline & OM1 & 9542 & 264 & $\mathrm{~b}$ & & & & & & & & & & & & \\
\hline & Cut 1 & 5453 & 188 & & 34 & 2.5 & $\mathrm{a}$ & 1.64 & 0.11 & & 0.22 & 0.01 & & 1.65 & 0.06 & $\mathrm{~b}$ \\
\hline & Cut 2 & 4089 & 201 & & 42 & 3.6 & B & 2.19 & 0.04 & A & 0.30 & 0.01 & & 1.76 & 0.07 & \\
\hline & OM2 & 9586 & 312 & $\mathrm{~b}$ & & & & & & & & & & & & \\
\hline & Cut 1 & 5399 & 209 & & 30 & 2.9 & $\mathrm{a}$ & 1.64 & 0.10 & & 0.25 & 0.01 & & 1.69 & 0.06 & $\mathrm{~b}$ \\
\hline & Cut 2 & 4187 & 189 & & 36 & 2.5 & B & 2.22 & 0.13 & A & 0.30 & 0.01 & & 1.84 & 0.05 & \\
\hline & $\mathrm{LSD}^{6}$ & 892 & & & 10 & & & n.s. & & & n.s. & & & 0.25 & & \\
\hline & $\mathrm{LSD}^{7}$ & & & & 13 & & & 0.51 & & & n.s. & & & n.s. & & \\
\hline \multirow{3}{*}{ Yr 3} & OM2 & 8651 & & & & & & & & & & & & & & \\
\hline & Cut 1 & 5499 & 169 & & 19 & 2.3 & & 1.52 & 0.05 & & 0.24 & 0.01 & & 1.60 & 0.08 & \\
\hline & Cut 2 & 3151 & 217 & & 24 & 2.8 & & 2.11 & 0.06 & & 0.31 & 0.01 & & 1.65 & 0.09 & \\
\hline
\end{tabular}

${ }^{1}$ The proportion of legumes was determined visually before harvest.

${ }^{2}$ Standard error of means. Yield data were averaged for the years 2001-2010, whereas data on nutrient concentrations were averaged for the years 2006-2010.

${ }^{3}$ Pairwise comparisons of yields (sum of two cuts) using LSD at the $5 \%$ level, where yields of the same crop not differing significantly between systems are denoted the same letter.

${ }^{4}$ Pairwise comparisons of clover content separate for each cut, where clover contents of the first cut not differing significantly between systems are denoted the same letter, whereas clover contents of the second cut not differing significantly between systems are denoted the same capital letter.

${ }^{5}$ Pairwise comparisons of nutrient concentrations separate for each cut, where concentrations of the first cut not differing significantly between systems are denoted the same letter, whereas concentrations of the second cut not differing significantly between systems are denoted the same capital letter.

${ }^{6} \mathrm{LSD}$ values at $5 \%$ level for the total yields (sum of two cuts) and that for clover content and nutrient concentrations of first cut.

${ }^{7} \mathrm{LSD}$ values at $5 \%$ level for clover content and nutrient concentrations of the second cut.

The $\mathrm{P}$ removal at harvest amounted to 70 and $72 \%$ of that applied in CA1 and CA2, respectively (Table 6). This percentage was somewhat larger for CM $(82 \%)$, and very high for the organic systems OM1 (217\%) and OM2 (182\%), indicating soil $\mathrm{P}$ mining in these systems.

As the system differences in terms of P losses in drainage and runoff were not statistically significant, quotients between these losses and applied or harvested $\mathrm{P}$ were not calculated.
3.3.3. Potassium. The $\mathrm{K}$ input was in the range of $23-200 \%$ of the K output (Table 7). The pattern of the K budgets was similar to that for P; all the organic systems had calculated $\mathrm{K}$ deficits, whereas all the conventional systems appeared to accumulate $\mathrm{K}$.

The amount of harvested $\mathrm{K}$ corresponded to $53 \%$ of that applied in CA1 and CA2 (Table 7). This proportion was somewhat higher in the mixed dairy system CM (66\%). In the organic systems OM1 and OM2 the $\mathrm{K}$ removal 
TABLE 5: Measured and estimated nitrogen flows $\left(\mathrm{kg} \mathrm{N} \mathrm{ha}^{-1}\right.$ year $\left.{ }^{-1}\right)$ and selected quotients $\left(\mathrm{kg} \mathrm{N} \mathrm{kg} \mathrm{N}^{-1}\right)$ in the cropping systems at Apelsvoll, mean $2001-2010^{1}$.

\begin{tabular}{|c|c|c|c|c|c|c|}
\hline \multirow{2}{*}{$\mathrm{N}$ flow } & \multicolumn{6}{|c|}{ Cropping system ${ }^{2}$} \\
\hline & CA1 & CA2 & OA & $\mathrm{CM}$ & OM1 & OM2 \\
\hline Fertilizer applied & 124.9 & 118.6 & 0.0 & 87.2 & 0.0 & 0.0 \\
\hline Cattle slurry applied & 0.0 & 0.0 & 0.0 & 68.8 & 57.5 & 82.4 \\
\hline Dry atmospheric depositions & 2.7 & 2.7 & 2.7 & 2.7 & 2.7 & 2.7 \\
\hline Wet atmospheric depositions & 7.2 & 7.2 & 7.2 & 7.2 & 7.2 & 7.2 \\
\hline $\mathrm{N}$ fixation by legumes & 0.0 & 0.0 & 34.0 & 14.3 & 57.4 & 59.1 \\
\hline $\mathrm{N}$ in seeds & 12.9 & 13.1 & 4.4 & 2.5 & 2.6 & 1.1 \\
\hline Sum field $\mathrm{N}$ input & 147.7 & 141.6 & 48.3 & 182.6 & 127.5 & 152.6 \\
\hline Harvest $^{3}$ & 117.4 & 99.7 & 43.5 & 118.4 & 111.7 & 130.5 \\
\hline $\mathrm{NH}_{3}$ and $\mathrm{NO}_{x}$ from applied fertilizer ${ }^{4}$ & 12.5 & 11.9 & 0.0 & 8.7 & 0.0 & 0.0 \\
\hline $\mathrm{NH}_{3}$ and $\mathrm{NO}_{x}$ from applied cattle slurry $y^{4,5}$ & 0.0 & 0.0 & 6.7 & 13.8 & 11.5 & 16.5 \\
\hline Direct $\mathrm{N}_{2} \mathrm{O}$ losses ${ }^{4}$ & 1.6 & 1.7 & 0.7 & 2.1 & 1.0 & 1.1 \\
\hline Drainage and runoff $\mathrm{N}$ & 44.2 & 26.7 & 29.3 & 19.9 & 25.6 & 15.9 \\
\hline Sum field N output & 175.7 & 140.0 & 80.2 & 162.8 & 149.9 & 164.0 \\
\hline Field N budget & -28.0 & 1.6 & -31.9 & 19.8 & -22.5 & -11.4 \\
\hline Harvested $\mathrm{N}^{6} /$ applied $\mathrm{N}$ & 0.83 & 0.84 & - & 0.73 & 1.86 & 1.54 \\
\hline Drainage + runoff $\mathrm{N}$ /applied $\mathrm{N}$ & 0.35 & 0.23 & - & 0.13 & 0.45 & 0.19 \\
\hline Drainage + runoff $\mathrm{N} /$ harvested $\mathrm{N}^{6}$ & 0.43 & 0.27 & 0.67 & 0.17 & 0.24 & 0.13 \\
\hline
\end{tabular}

${ }^{1}$ Timestep used is the agrohydrological year (May-April), thus, covering the period May 2001-April 2011.

${ }^{2}$ Each system covers 0.18 ha and consists of four rotation plots á 0.045 ha.

${ }^{3}$ Including the $\mathrm{N}$ removed with straw. Harvested grass-clover $\mathrm{N}$ was reduced by $10 \%$ to account for likely harvest-related losses under practical conditions (see Section 2).

${ }^{4}$ Calculated according to [24].

${ }^{5}$ Volatilization of $\mathrm{NH}_{3}-\mathrm{N}$ from mulched clover grass is not accounted for in [24], although it may be substantial [25]. It was, therefore, calculated in accordance with Korsaeth [6].

${ }^{6}$ Not including $\mathrm{N}$ removed with straw.

TABle 6: Measured and estimated phosphorus flows $\left(\mathrm{kg} \mathrm{Pha}^{-1}\right.$ year $\left.^{-1}\right)$ and selected quotients $\left(\mathrm{kg} \mathrm{P} k \mathrm{P}^{-1}\right)$ in the cropping systems at Apelsvoll, mean 2001-2010 ${ }^{1}$

\begin{tabular}{|c|c|c|c|c|c|c|}
\hline \multirow{2}{*}{ P flow } & \multicolumn{6}{|c|}{ Cropping system $^{2}$} \\
\hline & CA1 & CA2 & $\mathrm{OA}$ & $\mathrm{CM}$ & OM1 & $\mathrm{OM} 2$ \\
\hline Fertilizer & 29.8 & 29.5 & 0.0 & 15.0 & 0.0 & 0.0 \\
\hline Cattle slurry applied & 0.0 & 0.0 & 0.0 & 9.6 & 7.9 & 10.9 \\
\hline $\mathrm{P}$ in seeds & 2.6 & 2.7 & 0.7 & 0.5 & 0.5 & 0.2 \\
\hline Sum field P input & 32.5 & 32.1 & 0.7 & 25.1 & 8.4 & 11.1 \\
\hline Harvested $\mathrm{P}^{3}$ & 24.1 & 20.5 & 8.8 & 21.0 & 18.2 & 20.7 \\
\hline Drainage and runoff $\mathrm{P}$ & 0.2 & 0.1 & 0.2 & 0.3 & 0.2 & 0.2 \\
\hline Sum field P output & 24.3 & 20.7 & 8.9 & 21.2 & 18.4 & 20.9 \\
\hline Field P budget & 8.2 & 11.5 & -8.2 & 3.9 & -10.0 & -9.8 \\
\hline Harvested $\mathrm{P}^{4} /$ applied $\mathrm{P}$ & 0.72 & 0.70 & & 0.82 & 2.17 & 1.82 \\
\hline
\end{tabular}

${ }^{1}$ Timestep used is the agrohydrological year (May-April), thus, covering the period May 2001-April 2011.

${ }^{2}$ Each system covers 0.18 ha, and consists of four rotation plots á 0.045 ha.

${ }^{3}$ Including the P removed with straw. Harvested grass-clover P was reduced by $10 \%$ to account for likely harvest-related losses under practical conditions (see Section 2).

${ }^{4}$ Not including $\mathrm{P}$ removed with straw. 

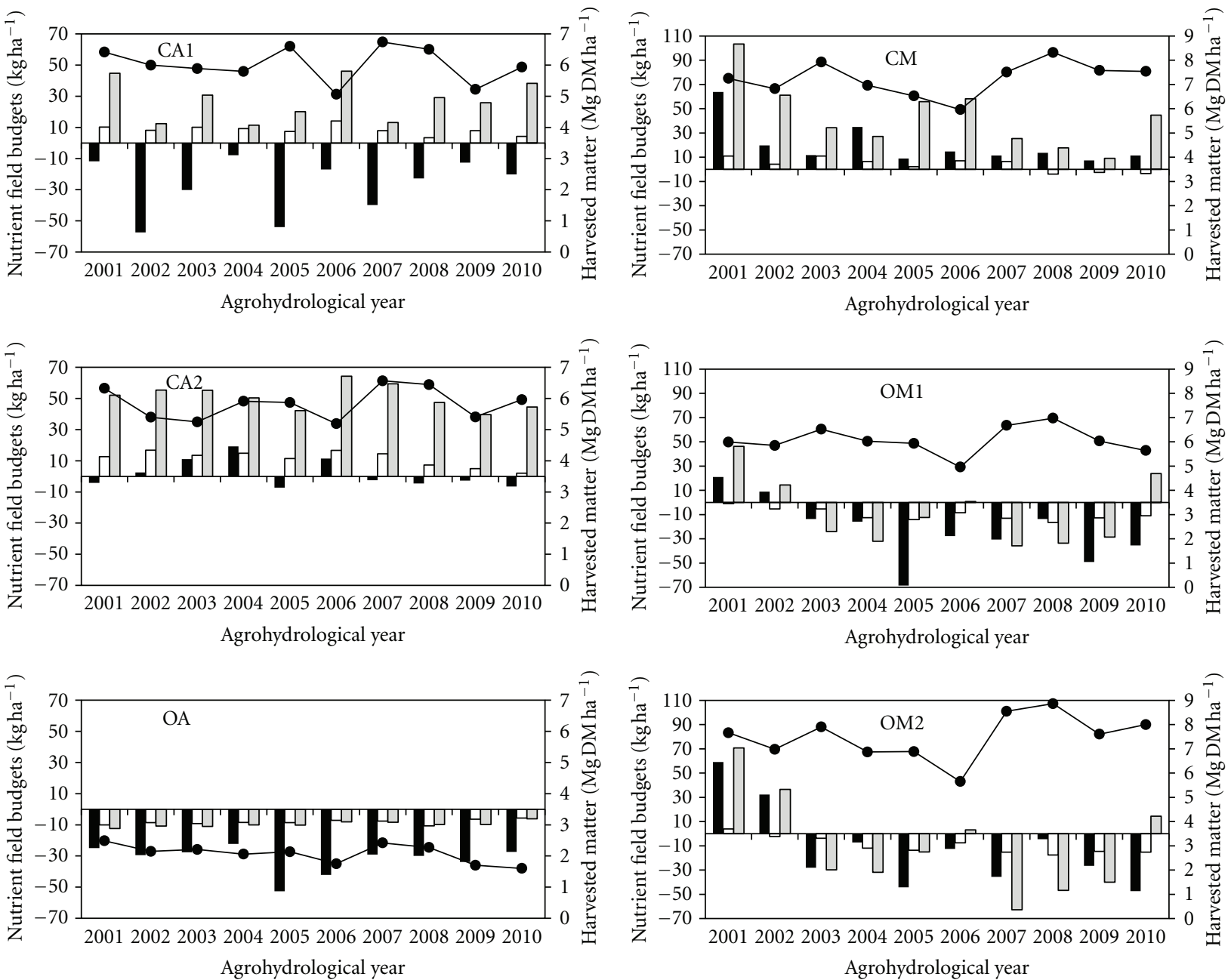

FIgURE 2: Annual (agrohydrological year) harvested dry matter yields averaged over crops (lines) (right $y$-axis) and soil system budgets for $\mathrm{N}$ (black bars), P (white bars), and K (grey bars) (left $y$-axis) for CA1 (conventional arable: upper left subplot), CA2 (conventional arable, environmentally sound: middle left subplot), OA (organic arable: lower left subplot), CM (conventional mixed dairy: upper right subplot), OM1 (organic mixed dairy: middle right subplot), and OM2 (organic mixed dairy with 75\% clover ley: lower right subplot).

at harvest was only slightly larger than the amount of $\mathrm{K}$ applied.

The sum of $\mathrm{K}$ lost via drainage and runoff was $7 \%$ and $5 \%$ of that applied in CA1 and CA2, respectively (Table 7). The corresponding percentages for the mixed dairy systems were less, ranging from $2-4 \%$.

The loss-to-harvest ratios for $\mathrm{K}$ followed a similar pattern as for $\mathrm{N}$, but at a lower level (Table 7). The arable systems had the largest ratios, with the highest value calculated for $\mathrm{OA}$. The differences were much smaller within the group of mixed dairy systems, with $\mathrm{N}$ losses ranging from $2-4 \%$ of the harvested $\mathrm{K}$.

\subsection{Changes in Topsoil Nutrient Content}

3.4.1. Nitrogen. The ignition loss did not differ significantly between 1999 and 2009, although the measurements appeared to be at a lower level in 2009 (Table 8, Figure 3(a)).
The tendency of reduction was particularly strong for CA1 $(P=0.054)$ and $\mathrm{OM} 2(P=0.088)$. Although the measured changes in ignition loss over time did not support the calculated $\mathrm{N}$ budgets substantially, the differences between systems in terms of ignition loss measured in 2009 reflected the $\mathrm{N}$ budgets very well (Figure 4(a)). A ranking of the systems in terms of measured ignition loss levels in 2009 was almost identical with a ranking based on the calculated $\mathrm{N}$ budgets.

3.4.2. Phosphorus. P-AL changed significantly in four of the six systems during the period 1996-2009 (Table 8, Figure 3(b)). The measurements in 2009 showed the same pattern of differences between the systems as did those in 2003, but with a greater magnitude. The measured differences in P-AL reflected the calculated P budgets well, although the measured declines in OM1 and OM2 were not significant (Table 8). There was a strong linear relationship 


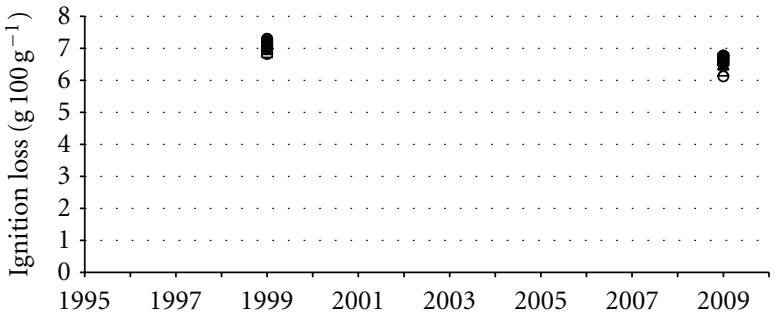

(a)

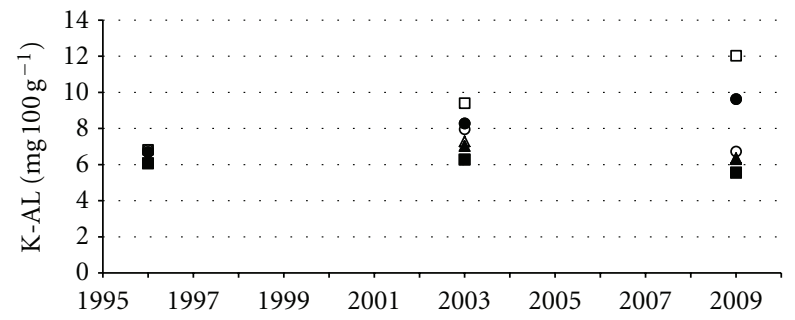

(c)

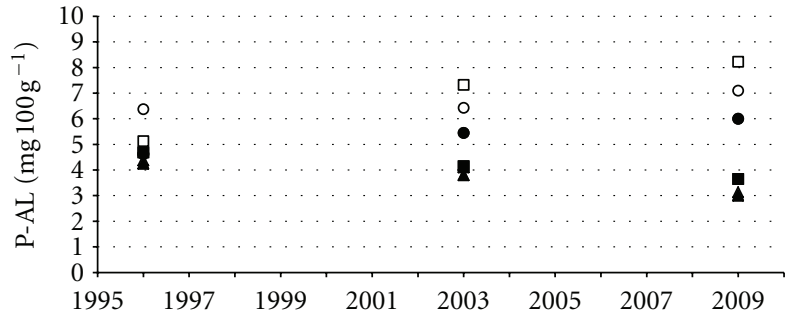

(b)

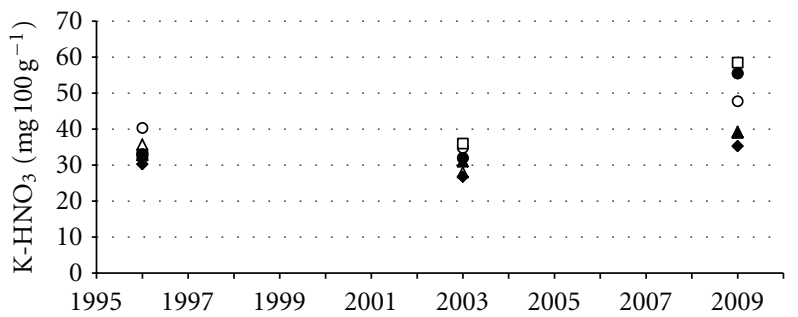

(d)

Figure 3: Topsoil $\left(0-25 \mathrm{~cm}\right.$ ) content of ignition loss (subplot A), P-AL (subplot B), K-AL (subplot C), and $\mathrm{K}-\mathrm{HNO}_{3}$ (subplot D) for the six cropping systems CA1 (conventional arable: $\bigcirc$ ), CA2 (conventional arable, environmentally sound: $\square$ ), OA (organic arable: $\triangle$ ), CM (conventional mixed dairy: •), OM1 (organic mixed dairy: $\mathbf{\Delta}$ ), and OM2 (organic mixed dairy with 75\% clover ley: $\mathbf{\square}$ ).

TABLE 7: Measured and estimated potassium flows $\left(\mathrm{kg} \mathrm{Kha}^{-1} \mathrm{year}^{-1}\right)$ and selected quotients $\left(\mathrm{kg} \mathrm{K} \mathrm{kg} \mathrm{K}^{-1}\right)$ in the cropping systems at Apelsvoll, mean 2001-2010.

\begin{tabular}{|c|c|c|c|c|c|c|}
\hline \multirow{2}{*}{ K flow } & \multicolumn{6}{|c|}{ Cropping system ${ }^{2}$} \\
\hline & CA1 & CA2 & $\mathrm{OA}$ & $\mathrm{CM}$ & OM1 & OM2 \\
\hline Fertilizer & 90.7 & 88.4 & 0.0 & 56.9 & 0.0 & 0.0 \\
\hline Cattle slurry applied & 0.0 & 0.0 & 0.0 & 89.2 & 74.7 & 101.8 \\
\hline Wet atmospheric depositions & 2.1 & 2.1 & 2.1 & 2.1 & 2.1 & 2.1 \\
\hline $\mathrm{K}$ in seeds & 11.4 & 11.4 & 0.9 & 0.6 & 0.6 & 0.3 \\
\hline Sum field $\mathrm{K}$ input & 104.2 & 101.9 & 3.0 & 148.8 & 77.4 & 104.2 \\
\hline Harvested $\mathrm{K}^{3}$ & 70.4 & 46.8 & 9.3 & 101.4 & 82.2 & 112.0 \\
\hline Drainage and runoff $\mathrm{K}$ & 6.6 & 4.1 & 3.3 & 3.6 & 3.3 & 2.3 \\
\hline Sum field K output & 77.0 & 50.9 & 12.6 & 105.1 & 85.4 & 114.3 \\
\hline Field K budget & 27.2 & 51.0 & -9.7 & 43.7 & -8.0 & -10.1 \\
\hline Harvested $\mathrm{K}^{4}$ /applied $\mathrm{K}$ & 0.53 & 0.53 & & 0.66 & 1.04 & 1.05 \\
\hline Drainage + runoff K/applied K & 0.07 & 0.05 & & 0.03 & 0.04 & 0.02 \\
\hline Drainage + runoff K/harvested $\mathrm{K}^{4}$ & 0.14 & 0.09 & 0.36 & 0.04 & 0.04 & 0.02 \\
\hline
\end{tabular}

${ }^{1}$ Timestep used is the agrohydrological year (May-April), thus covering the period May 2001-April 2011.

${ }^{2}$ Each system covers 0.18 ha and consists of four rotation plots á 0.045 ha.

${ }^{3}$ Including the $\mathrm{K}$ removed with straw. Harvested grass-clover K was reduced by $10 \%$ to account for likely harvest-related losses under practical conditions (see Section 2).

${ }^{4}$ Not including K removed with straw.

between P-AL measured in 2009 and the calculated P budgets of the systems (Figure 4(b)).

3.4.3. Potassium. K-AL followed a pattern similar to that of P-AL over the period 1996-2009, with increasing differences between systems over time (Figure 3(c)). The only significant differences between the measurements in 1996 and 2009 were found in CA2 and CM, which both showed increased levels of K-AL in 2009 (Table 8). The calculated K-deficits in the organic systems, and the K-surplus of CA1, could, thus, not be supported by the measured differences in K-AL over time. The differences between systems in terms of K-AL measured in 2009 corresponded, however, very well with the calculated K budgets (Figure 4(c)).

There was a significant increase in the topsoil content of $\mathrm{K}_{-} \mathrm{HNO}_{3}$ from 1996 to 2009 in all systems (Table 8 , Figure $3(\mathrm{~d})$ ). The rate of change decreased in the order $\mathrm{CA} 2>\mathrm{CM}>\mathrm{CA} 1>\mathrm{OM} 1>\mathrm{OM} 2>\mathrm{OA}$, a ranking which 
TABLE 8: Measured changes in selected chemical properties in topsoil $(0-25 \mathrm{~cm})$ for the last decade.

\begin{tabular}{|c|c|c|c|c|c|c|}
\hline Cropping system/year & CA1 & CA2 & $\mathrm{OA}$ & $\mathrm{CM}$ & OM1 & OM2 \\
\hline & \multicolumn{6}{|c|}{ Ignition loss $\left({\left.\mathrm{g} 100 \mathrm{~g}^{-1}\right)}\right.$} \\
\hline 1999 & 6.83 & 6.88 & 7.05 & 7.30 & 6.98 & 7.13 \\
\hline 2009 & 6.13 & 6.70 & 6.30 & 6.78 & 6.50 & 6.63 \\
\hline Change (2009-1999) & -0.70 & -0.18 & -0.75 & -0.53 & -0.48 & -0.50 \\
\hline \multirow[t]{2}{*}{$P$ value $^{1}$} & $0.054^{\text {n.s. }}$ & $0.608^{\text {n.s. }}$ & $0.204^{\text {n.s. }}$ & $0.152^{\text {n.s. }}$ & $0.265^{\text {n.s. }}$ & $0.088^{\text {n.s. }}$ \\
\hline & \multicolumn{6}{|c|}{ P-AL $\left(\mathrm{mg} 100 \mathrm{~g}^{-1}\right)$} \\
\hline 1996 & 5.38 & 4.00 & 4.25 & 4.00 & 3.75 & 3.88 \\
\hline 2009 & 7.10 & 8.23 & 3.13 & 6.00 & 3.00 & 3.65 \\
\hline Change (2009-1996) & 1.73 & 4.23 & -1.13 & 2.00 & -0.75 & -0.23 \\
\hline \multirow[t]{2}{*}{$P$ value } & 0.029 & 0.015 & 0.036 & 0.001 & $0.102^{\text {n.s. }}$ & $0.409^{\text {n.s. }}$ \\
\hline & \multicolumn{6}{|c|}{$\mathrm{K}-\mathrm{AL}\left(\mathrm{mg} 100 \mathrm{~g}^{-1}\right)$} \\
\hline 1996 & 6.75 & 6.75 & 6.13 & 7.13 & 6.13 & 6.00 \\
\hline 2009 & 6.73 & 12.0 & 6.35 & 9.63 & 6.30 & 5.55 \\
\hline Change (2009-1996) & -0.03 & 5.28 & 0.23 & 2.50 & 0.18 & -0.45 \\
\hline \multirow[t]{2}{*}{$P$ value } & $0.942^{\text {n.s. }}$ & 0.043 & $0.362^{\text {n.s. }}$ & 0.022 & $0.188^{\text {n.s. }}$ & $0.517^{\text {n.s. }}$ \\
\hline & \multicolumn{6}{|c|}{$\mathrm{K}-\mathrm{HNO}_{3}\left(\mathrm{mg} 100 \mathrm{~g}^{-1}\right)$} \\
\hline 1996 & 31.1 & 28.3 & 30.9 & 28.6 & 29.1 & 26.0 \\
\hline 2009 & 47.8 & 58.5 & 39.3 & 55.5 & 39.0 & 35.3 \\
\hline Change (2009-1996) & 16.6 & 30.3 & 8.38 & 26.9 & 9.88 & 9.25 \\
\hline$P$ value & 0.012 & 0.007 & 0.010 & 0.003 & 0.001 & 0.037 \\
\hline
\end{tabular}

${ }^{1}$ Level of significance for the pairwise $t$-test of differences. Nonsignificance at the $5 \%$ level is denoted ${ }^{\text {n.s }}$.

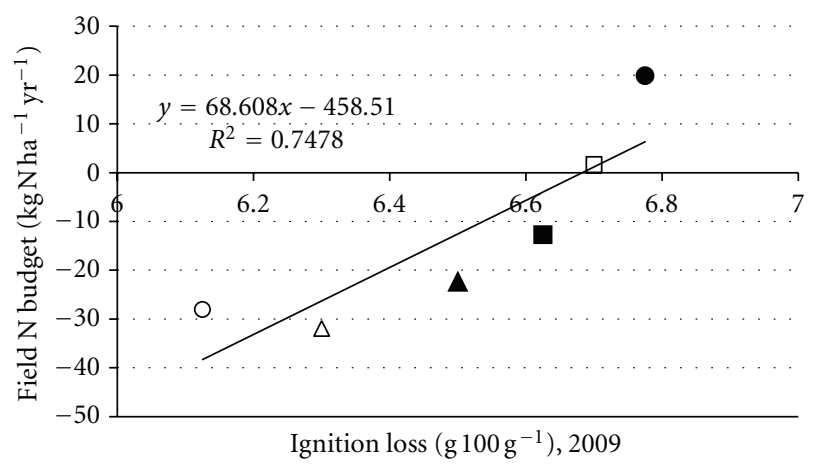

(a)

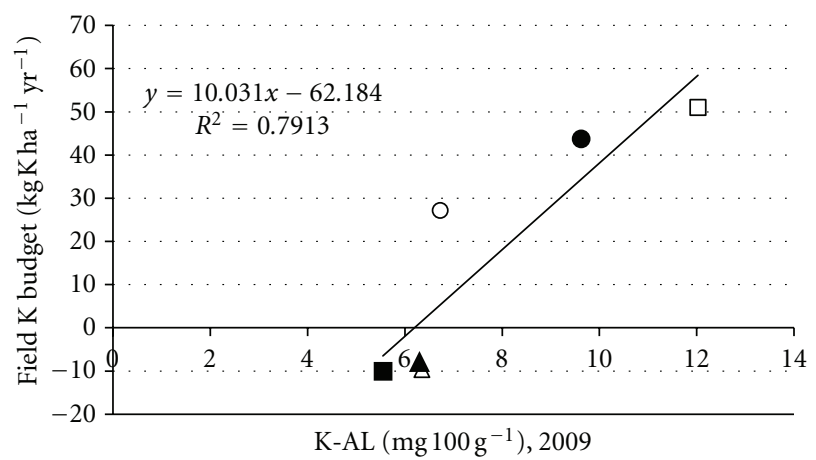

(c)

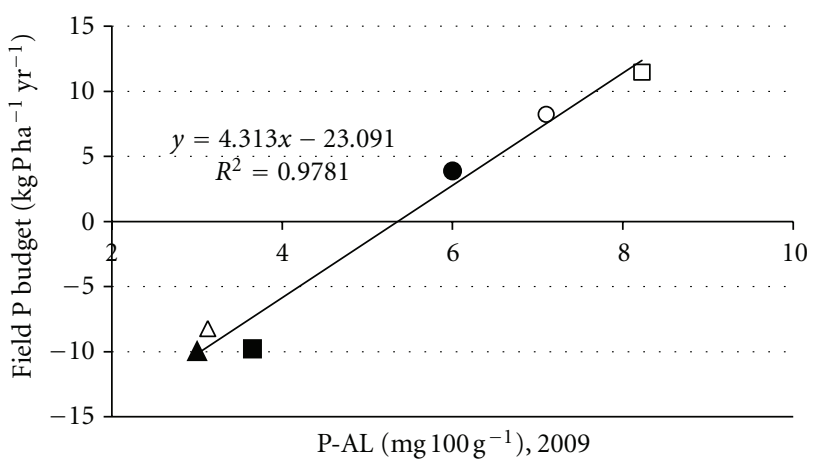

(b)

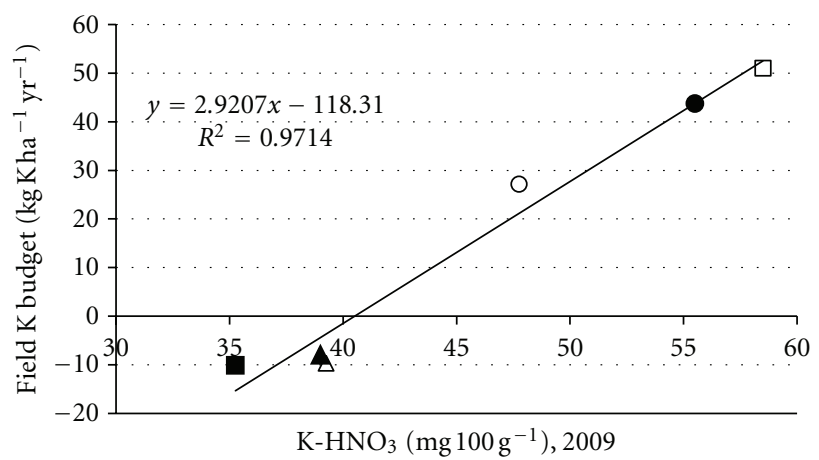

(d)

Figure 4: Calculated soil system budgets of N, P, and K for the years 2001-2010 plotted, respectively, against ignition loss (subplot A), P-AL (subplot B), K-AL (subplot C), and $\mathrm{K}_{-} \mathrm{HNO}_{3}$ (subplot D) for the six cropping systems CA1 (conventional arable: $\bigcirc$ ), CA2 (conventional arable, environmentally sound: $\square$ ), OA (organic arable: $\triangle$ ), CM (conventional mixed dairy: •), OM1 (organic mixed dairy: $\Delta$ ), and OM2 (organic mixed dairy with $75 \%$ clover ley: $\mathbf{\square}$ ). 
corresponded well with a ranking of the calculated $\mathrm{K}$ budgets. The relation between the soil measurements in 2009 and the calculated $\mathrm{K}$ budgets was even stronger for $\mathrm{K}-\mathrm{HNO}_{3}$ than it was for K-AL (Figure 4(d)).

\section{Discussion}

4.1. Yields. Both cereal yield levels and relative yield differences between systems followed the same pattern for the whole period 2001-2010 as for the years 2001-2004, which were discussed by Korsaeth [6]. Briefly, the yield differences were larger amongst the arable systems than amongst the mixed dairy systems. The low yields in OA may be explained by $\mathrm{P}$ and $\mathrm{K}$ deficits, as indicated by the negative $\mathrm{P}$ and $K$ budgets and the significant reduction in plant available topsoil $\mathrm{P}$, and due to the lack of chemical plant protection. More foliar diseases were generally observed on cereals in the organic systems than in the other systems (data not shown).

The lack of significant differences in measured potato parameters between the two cropping systems (CA1 and CA2) is partly in accordance with the findings of Riley and Ekeberg [27], who compared spring and autumn ploughing at different depths $(10,20$, and $30 \mathrm{~cm})$ with tine harrowing only in spring, on the same soil type at a nearby location. They found the same potato fresh weight yields in all treatments, but the tuber dry matter concentration was significantly lower in potatoes grown without ploughing.

Among the mixed dairy systems, the organically grown cereal yields were also lower than those grown conventionally. However, due to much smaller differences in nutrient regime, the differences between mixed dairy systems were less than those between arable systems. The most likely reasons for inferior yields in the organic mixed dairy systems relative to the conventional mixed dairy system were, as for the arable systems, suboptimal nutrition and a lack of plant protection.

The yield pattern of grass clover ley was also unchanged in 2005-10 compared with the first four years of the decade [6]. The high yields of the organic leys may be explained partly by their $\mathrm{N}$ fixation, which was estimated to be much greater in the organic leys than in the conventional leys. This was a result of the significantly higher proportions of clover in the organic leys and less suppression of $\mathrm{N}$ fixation by the use of inorganic $\mathrm{N}$ fertilizer. The reduced grass clover yields in the 3rd ley year of OM2 may be due to the reduced proportion of clover compared with the first two ley years.

The long period of active nutrient uptake by grass and clover may also partly explain the relatively high organic ley yields. A longer uptake period increases the utilization of less readily available nutrients (e.g., nutrients in organic form), since the mineralization of such nutrients occurs throughout the cropping season. Smaller yield differences between organic and conventional cropping for grass clover ley than for cereals have been reported previously for this experiment [28].

In a review of a number of Swedish field studies, Bergström et al. [29] reported that crop yields in organic rotations were reduced by 20 to $80 \%$, compared with the same crops in conventional rotations. These authors explained this in terms of higher $\mathrm{N}$ deficiency, more weed competition, and greater infestation of crop diseases in the organic systems.

\subsection{Soil System Nutrient Budgets and Nutrient Concentrations of Topsoil and Crops}

4.2.1. Nitrogen. The large calculated deficits found for the arable systems CA1 and OA in the first part of the decade [6] were sustained. The suggested net soil $\mathrm{N}$ depletion corresponded to a relative decay rate of the topsoil $(0-25 \mathrm{~cm})$ $\mathrm{N}$ content of $0.4 \% \mathrm{yr}^{-1}$. This corresponds well with Riley and Bakkegard [30], who compared soil samples taken in 1991 and in 2001 from 291 arable fields located throughout southeast Norway. They found that the percentage relative decline rate of SOM was approximately one tenth of the initial percentage of organic matter in soil over the decade. In the present study, there was a strong tendency $(P=0.054)$ towards reduced ignition loss for CA1 in 2009 compared with 1999; but this was not the case for OA.

Comparing conventional and organic cropping systems in a pipe-drained plot experiment in Sweden, Torstensson et al. [31] also reported an $\mathrm{N}$ deficit $\left(-18 \mathrm{~kg} \mathrm{Nha}^{-1} \mathrm{yr}^{-1}\right.$, not including denitrification, $\mathrm{N}$ in seeds and atmospheric depositions) for a conventional arable rotation (CON, barleyoat-spring wheat-barley-oat-potato) comparable with CA1. They tested additionally an arable organic system with green manure as the only $\mathrm{N}$ source (OGM, oat-green manure-spring wheat-oat-green manure-potato), comparable with $\mathrm{OA}$ and found a positive soil system $\mathrm{N}$ budget $\left(13 \mathrm{~kg} \mathrm{~N} \mathrm{ha}^{-1} \mathrm{yr}^{-1}\right)$ in contrast to the present findings. In the experiment of Torstensson et al. [31], the proportion of green manure was, however, larger than in our case $(33 \%$ versus $25 \%$ ), which resulted in $37 \mathrm{~kg} \mathrm{Nha}^{-1} \mathrm{yr}^{-1}$ more $\mathrm{N}$ fixation and $20 \mathrm{~kg} \mathrm{~N} \mathrm{ha}^{-1} \mathrm{yr}^{-1}$ less harvested $\mathrm{N}$, compared with OA.

The only arable system which appeared to have a balanced $\mathrm{N}$ budget was CA2. This may mainly be explained by its comparative low leaching and runoff $\mathrm{N}$ losses, which represent the main difference between CA1 and CA2 with regard to $\mathrm{N}$ flows. The findings indicate that reduced tillage counteracted soil $\mathrm{N}$ mining, which is a commonly reported result (e.g., [32]). Another factor which may have contributed to prevent soil $\mathrm{N}$ mining in CA2 is that straw was not removed. Straw incorporation has a well-known positive effect on the soil organic $\mathrm{N}$ content (e.g., [33]).

The conventional mixed dairy system CM had a calculated $\mathrm{N}$ surplus over the decade, which indicates that the system probably increased its soil organic matter content. Conservation of or an increase in soil $\mathrm{N}$ has also been reported for other rotations containing pasture or ley receiving organic $\mathrm{N}$ on relatively $\mathrm{N}$-rich $\left(>2.0 \mathrm{~g} \mathrm{~kg}^{-1}\right)$ soils $[32,33]$. The opposite was found in the organic system OM1, with the same crop rotation and tillage as CM, but with a calculated $\mathrm{N}$ deficit of $23 \mathrm{~kg} \mathrm{~N} h a^{-1} \mathrm{yr}^{-1}$, indicating that the relatively high production has been maintained at the cost of the soil organic N pool. Similarly, Steinshamn et al. [34] reported an annual $\mathrm{N}$ deficit of $16 \mathrm{~kg} \mathrm{Nha}^{-1}$, not including $\mathrm{N}$ leaching and denitrification, at the field level in an organic 
crop rotation with $50 \%$ grassland (barley, forage rape + Italian ryegrass, oats + peas, 3-year grassland).

The slightly negative $\mathrm{N}$ budget of OM2 $\left(-16 \mathrm{~kg} \mathrm{Nha}^{-1}\right)$ shows that a high proportion of grass clover ley in the rotation does not guarantee a balanced $\mathrm{N}$ budget. By comparison, Syväsalo et al. [35] reported an even larger N deficit $\left(-31 \mathrm{~kg} \mathrm{Nha}^{-1} \mathrm{yr}^{-1}\right.$, not including ammonia emissions, deposition, or $\mathrm{N}$ in seeds) in an organic grass clover ley receiving $130 \mathrm{~kg} \mathrm{Nha}^{-1}$ in cattle slurry. An extra year of grass clover ley instead of wheat in the OM2 rotation resulted in the largest calculated amounts of available cattle slurry for this system $\left(82 \mathrm{~kg} \mathrm{Nha}^{-1}\right)$, but the $\mathrm{N}$ fixation was apparently much less effective in the additional ley year than in the previous two ley years. The estimated $\mathrm{N}$ fixation of the third ley year was only $43 \mathrm{~kg} \mathrm{Nha}^{-1} \mathrm{yr}^{-1}$, compared with 82 and $88 \mathrm{~kg}$ in the 1 st and 2 nd ley year, respectively.

The annual nutrient budgets of the mixed dairy systems showed more positive figures for 2001 and 2002 compared with the following eight years. This was a result of too high yield expectations when calculating the initial amount of slurry available for these systems in 2001. The number of cows which each farming system could sustain, and, thus, the amount of slurry available for the crops, was calculated from the average total available feed in the system during the previous three years (sliding mean). The initialization problem was, thus, gradually levelled out.

The calculated changes in soil $\mathrm{N}$, that is, misbalanced soil system $\mathrm{N}$ budgets, were in general poorly supported by the measured changes in topsoil ignition loss since 1999, which were all nonsignificant. Considering the large differences in the measured $\mathrm{N}$ flows between the systems, it is very unlikely that the SOM level of 1999 would have been sustained in all systems over the following decade. One explanation of the mismatch could be an over- or underestimation of the estimated gaseous $\mathrm{N}$ losses, which were the most uncertain $\mathrm{N}$ flows in the calculated budgets. If these losses were largely overestimated, the calculated deficits of CA1, OA, OM1, and OM2 would have been reduced, but the calculated surplus of OM would have increased, and vice versa. Another explanation could be that some organic matter has been transported from topsoil to subsoil. Such a translocation of organic matter may have taken place, but it seems unlikely that this process has diverged significantly between systems with more or less the same crop rotation.

The relative differences between the systems in 2009 matched the calculated soil system $\mathrm{N}$ budgets much better than the differences found between sampling times, indicating that the 1999 data may include some random variation. The relation between ignition losses in 2009 and the N budgets indicated that ignition loss would equilibrate at $67 \mathrm{~g} \mathrm{~kg}^{-1}$ with a balanced $\mathrm{N}$ budget. This corresponds to an SOM content of $47 \mathrm{~g} \mathrm{~kg}^{-1}$, calculated with a pedotransfer function developed solely for this site $(\mathrm{SOM}=0.81 \times$ ignition loss (\%) $-0.038 \times$ clay $(\%)-0.70),[21])$.

The significant differences between systems in terms of $\mathrm{N}$ concentrations of the harvested crops were few and reflected poorly the differences in fertilization regime and soil system $\mathrm{N}$ budgets. Greenwood et al. [36] developed a model linking
$\mathrm{N}$ concentration in plant DM to growth rate and to plant mass per unit area. They found that subcritical values of $\mathrm{N}$ concentration during growth affected the growth rate. In order to define whether any of the crops in the present study were $\mathrm{N}$ limited, measurements of $\mathrm{N}$ concentration during crop growth and not at harvest would, thus, have been required.

4.2.2. Phosphorus. Conventional arable cropping appeared to give relatively large surpluses of $\mathrm{P}$. In the past, more emphasis, in Norway, was placed on adjusting $\mathrm{N}$ fertilizer rates to crop requirements than to adjusting P rates. In 20072008 there was a change in the fertilizer recommendations for $\mathrm{P}$ in Norway, with a reduction of approx. 25\% for cereals and grasses and 30\% for potatoes. This prompted the fertilizer market leader in Norway (market share > 90\%) to increase the N:P-ratio of their most used compound fertilizers, from 5.3 to 7.3 for cereals and from 2.2 to 3.0 for potatoes, thus reducing the amounts of $\mathrm{P}$ for a given amount of $\mathrm{N}$.

The organic arable system did not receive any $\mathrm{P}$, and the production was thus entirely dependent on $\mathrm{P}$ supply from the soil. The negative soil system budget of $8 \mathrm{~kg} \mathrm{Pha}^{-1} \mathrm{yr}^{-1}$ was the same as that found in a stockless organic farm (red cloverwinter wheat-spring beans-spring cereal) in the UK [15]. The results show that in stockless organic farming systems, some form of external $\mathrm{P}$ addition becomes unavoidable sooner or later (depending on the size of the initial $\mathrm{P}$ pool and the ability of the soil to deliver plant available P). Berry et al. [15] showed that a system comparable with OA was almost in balance in terms of $\mathrm{P}$ when it received rock phosphate. From a resource economics point of view, it is questionable; however, whether the use of untreated rock phosphate is a good strategy, considering its low plant availability [37]. An alternative could be to use organic waste, such as biogas residue from household waste, which has been shown to be a valuable and inexpensive source of plant nutrients [38].

The conventional mixed dairy system had a field surplus of almost $4 \mathrm{~kg} \mathrm{Pha}^{-1} \mathrm{yr}^{-1}$, suggesting an unnecessary use of a limited resource. This appears to be no exception. In a comparable farming system in northern Sweden, Bengtsson et al. [39] reported a $\mathrm{P}$ surplus of $5 \mathrm{~kg} \mathrm{Pha}^{-1} \mathrm{yr}^{-1}$. The problem seems to be even worse on conventional dairy farms, that is, those with no or a very low proportion of arable crops. The $\mathrm{P}$ surplus on such farms is assumed to vary from 10 to $72 \mathrm{~kg} \mathrm{ha}^{-1}$ in Europe (Pfimlin et al. 2006, cited by [40]).

The organic mixed dairy systems produced at the cost of their indigenous soil $\mathrm{P}$ pool, with a total deficit of about $10 \mathrm{~kg} \mathrm{Pha}^{-1} \mathrm{yr}^{-1}$. This was not surprising, considering that there was no $\mathrm{P}$ input to these systems, except for that in seeds. Even when some feed is purchased, P deficits are commonly reported. Berry et al. [15] reported soil surface budgets (i.e., maximum root depth as lower boundary) of $-3 \mathrm{~kg} \mathrm{Pha}^{-1} \mathrm{yr}^{-1}$ in a mixed dairy system in the UK (ley cropped in 3 out of 5 years, farm number 3). Steinshamn et al. [34] found a deficit between inputs and produce (losses not considered) in an organic dairy farming system in Norway of $6.3 \mathrm{~kg} \mathrm{P} \mathrm{ha} \mathrm{yr}^{-1}$. 
All the significant changes in topsoil P-AL from 1996 to 2009 were in the same direction as the corresponding calculated soil system $\mathrm{P}$ budgets. The budget calculations were also supported by the very strong relation between the topsoil level of AL-extractable P in 2009 and the calculated soil system budget. The results clearly show the effect of both overfertilization and suboptimal $P$ fertilization on the plant availability of $P$ in soil.

In the present study, $\mathrm{P}$ losses to subsoil, that is, below root depth, were considered to be negligible. On a comparable soil in the long-term fertilizer trials at Møystad in S.E. Norway, Riley [41] found no effect of $\mathrm{P}$ treatment (no $\mathrm{P}$ addition, $\mathrm{P}$ in mineral fertilizer, or $\mathrm{P}$ in animal manure) below $40 \mathrm{~cm}$ depth. In contrast, Verloop et al. [40], studying intensive dairy farming systems, found that some topsoil $\mathrm{P}$ was transported to subsoil and that the $\mathrm{P}$ accumulation in the deeper layers practically equalled the $\mathrm{P}$ depletion in the upper topsoil. Their experiment was, however, run on a light sandy soil, characterized by a $0.3 \mathrm{~m}$ anthropogenic topsoil overlaying a layer of yellow sand hardly penetrable by roots.

With an assumed balanced P budget, P-AL appeared to equilibrate at $54 \mathrm{mg} \mathrm{P} \mathrm{kg}^{-1}$, a level which is normally considered adequate for optimum growth. In the longterm trials at Møystad, Ekeberg and Riley [8] also found a strong relationship between topsoil P-AL and P balance ( $\mathrm{P}$ applied via fertilizer and/or farmyard manure minus $\mathrm{P}$ removed by harvest) for the period 1922-1983. They reported that $\mathrm{P}-\mathrm{AL}$ equilibrated at $25-30 \mathrm{mg} \mathrm{P} \mathrm{kg}^{-1}$ when the application of $\mathrm{P}$ equalled the removal of $\mathrm{P}$ by crops. This equilibrium point rose to about $40 \mathrm{mg} \mathrm{P} \mathrm{kg}^{-1}$ in the period 1983-2003 (H. Riley, personal communication). Experiences from an intensive dairy farm in The Netherlands, where Pequilibrium fertilization (i.e., balancing $\mathrm{P}$ inputs via fertilizer and manure with $\mathrm{P}$ in crop products) is performed, has shown that the soil available P-status differs between crop rotations.

The $\mathrm{P}$ content of the crops did not differ between the systems, and the herbage concentrations of $\mathrm{P}$ were in the range of $0.2-0.3 \%$, a level which is regarded as adequate [42]. In comparison, Mathews et al. [43] considered $0.2-0.34 \% \mathrm{P}$ to be the critical concentration for cool-season grasses, that is, a concentration level below which a $10 \%$ yield drop is expected. It, thus, appears that the grass clover growth was not $\mathrm{P}$ limited in the organic mixed dairy systems, in spite of the continuous soil P depletion of these systems.

4.2.3. Potassium. The potassium soil system budgets showed that the conventional arable systems had unnecessarily high levels of $\mathrm{K}$ fertilization. As for $\mathrm{P}$, the change in the compound fertilizers (from 2009) also altered the amount of $\mathrm{K}$ relative to $\mathrm{N}$, with a $\mathrm{N}$ : K-ratio increasing from 2.1 to 2.2 for cereal fertilizer and from 0.65 to 0.67 for potato fertilizer. Although this change has some importance for practical farming, it did not influence the results presented here.

In contrast to the present findings, Torstensson et al. [31] reported a small $\mathrm{K}$ deficit $\left(-3 \mathrm{~kg} \mathrm{Kha}^{-1} \mathrm{yr}^{-1}\right)$ in a 6 year conventional rotation with five years of spring cereals and one year with potatoes, comparable with CA1.
Additionally, they found a large deficit $\left(-28 \mathrm{~kg} \mathrm{Kha}^{-1} \mathrm{yr}^{-1}\right)$ in a similar crop rotation but with ryegrass grown as a catch crop after each main crop, comparable with CA2. The contrasting findings of Torstensson et al. [31] may largely be explained by the K leaching, which were 5-7 times larger in their experiment than in the present study. The literature appears inconclusive, however, when it comes to $\mathrm{K}$-budgets for conventional arable cropping systems. This was well illustrated by Heming [44], who studied a large number of fields in southern England, reporting $\mathrm{K}$ budgets ( $\mathrm{K}$ applied in fertilizer minus $\mathrm{K}$ in crop) ranging from -40 to $+70 \mathrm{~kg} \mathrm{Kha}^{-1} \mathrm{yr}^{-1}$.

The organic arable system OA had a calculated K-deficit. Stockless organic systems without any form of $\mathrm{K}$ application are bound to result in negative $\mathrm{K}$ budgets, as has been commonly reported (e.g., $[15,31,45])$. Interestingly, the calculated deficit in OA was of the same magnitude as the calculated deficits of the two organic mixed dairy systems (OM1 and OM2). The relatively large inputs of $\mathrm{K}$ in applied slurry in the mixed dairy systems, thus, appeared to be more than outweighed by large $\mathrm{K}$ export via harvested material. Reviewing a range of cropping systems in northern Europe, Öborn et al. [46] summarized that negative farm gate and soil surface $\mathrm{K}$ budgets are especially common in organic farming. This was supported by Øgaard and Hansen [47], who found negative $\mathrm{K}$ budgets in grassland fields on 23 out of 26 organic farms in Norway. In a study of three longterm field experiments with mixed cropping systems (six year rotations with $2 / 6$ or 3/6 ley) on sandy loam soils over the 18 year period 1997-2004, Andrist-Rangel et al. [48] reported negative $\mathrm{K}$ budgets (input minus crop offtake) for organic systems in the range of -22 to $-75 \mathrm{~kg} \mathrm{Kha}^{-1} \mathrm{yr}^{-1}$. They also found, however, that a conventional mixed cropping system had negative field budgets during the same period, ranging from -21 to $-60 \mathrm{~K} \mathrm{ha}^{-1} \mathrm{yr}^{-1}$, in contrast to the conventional mixed cropping system of the present study (CM), which had a calculated surplus of $44 \mathrm{~kg} \mathrm{Kha}^{-1} \mathrm{yr}^{-1}$. On the other hand, Bengtsson et al. [39] reported a K surplus of $39 \mathrm{~kg} \mathrm{~K} \mathrm{ha}^{-1} \mathrm{yr}^{-1}$ in a comparable conventional system in northern Sweden.

The only significant changes in measured topsoil K$\mathrm{AL}$ were the increase in CA2 and $\mathrm{CM}$, in correspondence with their large calculated field $\mathrm{K}$ surpluses. The relative differences between systems in terms of calculated $\mathrm{K}$ budgets were well reflected in the relative differences between changes of $\mathrm{K}-\mathrm{HNO}_{3}$ and there was a clear relation between $\mathrm{K}$ budgets and measured levels of both K-AL and $\mathrm{K}-\mathrm{HNO}_{3}$ in 2009 . The relatively large, negative soil system $\mathrm{K}$ budgets for the organic systems were, however, not reflected by the soil measurements. Could it be that the soil system K budgets were largely underestimated (i.e., underestimated inputs and/or overestimated outputs)?

Errors in $\mathrm{K}$ mass budgets are not an uncommon phenomenon (e.g., [46]). It seems unlikely, however, that such errors alone could explain the lack of fit between the calculated $\mathrm{K}$ budgets and the soil $\mathrm{K}$ measurements. For example, the unfertilized system OA would need a budget correction of about $10 \mathrm{~kg} \mathrm{Kha}^{-1} \mathrm{yr}^{-1}$, in order to achieve a balanced soil system $\mathrm{K}$ budget, 
which would reflect the K-AL data (i.e., no significant difference between 1996 and 1999). Such a change would be of the same magnitude as the entire (current) calculated $\mathrm{K}$ off-take by harvest, and it would correspond to more than $330 \%$ of the total $\mathrm{K}$ input or $300 \%$ of the $\mathrm{K}$ measured in drainage and runoff. Moreover, the calculated depletions of $\mathrm{K}$ in the organic systems are well supported by relevant comparisons in the literature, as discussed above.

Another, and more likely, explanation of the poor relation between soil system $\mathrm{K}$ budgets and changes in soil $\mathrm{K}$ measurements over time, could be that the weathering of primary minerals has released $\mathrm{K}$ in amounts compensating for the calculated $\mathrm{K}$ depletion. Annual weathering rates for different Norwegian and Swedish soils have been estimated to range from 3 to $82 \mathrm{~kg} \mathrm{Kha}^{-1}$ [49]. Øgaard and Hansen [47], looking at $\mathrm{K}$ uptake and requirement in organic grassland farming in Norway, found that $\mathrm{K}$ uptake from reserve K, that is, $\mathrm{K}$ located in the interlayers of the sheet silicates in the soil, was positively related to the acid soluble $\mathrm{K}$ content (i.e., $\mathrm{K}-\mathrm{HNO}_{3}$ minus $\mathrm{K}-\mathrm{AL}$ ) of the soil. In the present study,

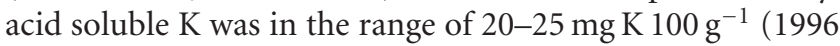
values), which corresponds to a potential uptake of reserve $\mathrm{K}$ between 30 and $110 \mathrm{~kg} \mathrm{Kha}^{-1} \mathrm{yr}^{-1}$, based on the findings of $\emptyset$ gaard and Hansen [47].

The considerations above relate to the topsoil. Additionally, there may have been substantial $\mathrm{K}$ uptake from the subsoil, particularly in systems with negative soil system budgets. Experiments using a $\mathrm{K} / \mathrm{Rb}$ isotope dilution method on loess-parabrown soils in N. Germany have showed that the subsoil ( $>30 \mathrm{~cm}$ depth) supplied between 9 and $70 \%$ of the total $\mathrm{K}$ uptake in spring wheat [50].

The data give no reason to assume that the availability of $\mathrm{K}$ was limiting for yield formation. In the future, separate analyses of grasses and legumes will nevertheless be performed, to enable a better assessment of the critical nutrient levels of the forage crops.

4.3. Implications for Future Cropping Systems. Agronomic practices affect the balance between utilization and removal of plant available nutrients in soil. Where the reserves of potentially available nutrients (e.g., organic $\mathrm{N}$, organic/fixed $\mathrm{P}$, and fixed $\mathrm{K}$ ) are large, low input farming systems may maintain productivity at the cost of a gradual decline of the soil nutrient pools. It should be emphasised, however, that soil $\mathrm{P}$ mining is to be considered as an equally serious depletion of a limited resource as the mining of rock P for producing mineral fertilizer. In future agricultural systems, one main challenge is to close the $\mathrm{P}$ cycle. Today, a large share of harvested $\mathrm{P}$ ends up in persistent chemical compounds due to the widespread use of coagulants (e.g., aluminium and iron) to remove $\mathrm{P}$ from sewage [51]. One step in the right direction is to use biogas residue from household waste, as mentioned above, as a nutrient source. Such a practice has from 2011 been integrated into the management of the organic OA system of the current study, in order to improve its nutrient balance.

Nitrogen may be fixed biologically in sufficient amounts in clover ley dominated systems. Systems which have an $\mathrm{N}$ input based on green manure appear, however, to be very area-demanding, and the practice of leaving large amounts of $\mathrm{N}$-rich material unharvested leads to severe risks for $\mathrm{N}$ losses to the environment [6]. The present study shows that a good alternative is to use moderate amounts of fertilizer, combined with steps to reduce the risk of losses, such as the use of spring tillage, catch crops, and split application of fertilizer. Such a system (i.e., CA2) has previously been shown to have the lowest ratio of $\mathrm{N}$ loss to food production [6].

Potassium is often given relatively little attention when studying agricultural systems, probably due to the absence of direct, negative environmental impacts associated with $\mathrm{K}$ losses. Moreover, many soils show a remarkable capacity for replacing removed plant available $\mathrm{K}$ through weathering and, thus, counteracting negative effects (i.e., plant $\mathrm{K}$ deficiency) when soil $\mathrm{K}$ mining occurs, as shown in this study. In the long term, however, all systems require a balanced supply of $\mathrm{K}$, which implies that most organic farmers today need to consider means to enhance the $\mathrm{K}$ input to their farms. This study highlights also the need for balancing $\mathrm{K}$, along with $\mathrm{N}$ and $\mathrm{P}$, in conventional systems, as there is a risk for an oversupply of $\mathrm{K}$ in these systems. Oversupply means that the indirect environmental impacts, that is, those associated with the manufacturing and transport of $\mathrm{K}$ fertilizer, are unnecessarily increased.

To perform a thorough evaluation of agricultural systems in terms of environmental impact, such as their global warming potential, all processes governing the manufacturing and transport of input factors (not only those for fertilizer) should be considered. This points toward the need for life cycle assessment (LCA) studies, which use a holistic approach for the evaluation of a system's environmental impacts (e.g., [52]). An LCA study of the systems included in the present paper is currently in preparation.

\section{Conclusions}

Differences in cereal yields between organically and conventionally managed systems are larger in arable rotations than those in mixed cropping systems including ley and animal husbandry, mainly due to improved nutrition through $\mathrm{N}$ fixation in the ley and the availability of animal manure in the latter group.

The yield differences for grass clover leys are smaller between the two management types (i.e., organic versus conventional) than those of cereals, due to lower disease pressure in grasses and better nutrition, resulting from $\mathrm{N}$ fixation and better utilization of mineralised nutrients (i.e., long period of active uptake).

Arable cropping may result in soil $\mathrm{N}$ mining, even when fertilized with normal to high amounts of $\mathrm{N}$, due to high potential for losses and poor utilization of mineralised $\mathrm{N}$. The use of $25 \%$ of the production area for green manure production is insufficient as an $\mathrm{N}$ source alone to balance the $\mathrm{N}$ losses and the off-take by harvest, on a fertile soil with high yield potential. Arable cropping, which comprises the use of reduced tillage, catch crops, and moderate amounts of fertilizer appears, however, to balance the $\mathrm{N}$ flows at field 
level. The use of $\mathrm{P}$ and $\mathrm{K}$ fertilizer in arable crop production may be used to balance the respective nutrient flows but it should be used with care, as over supply is a great risk.

Mixed dairy systems, producing both cereals and fodder crops, risk an undersupply of both $\mathrm{N}, \mathrm{P}$, and $\mathrm{K}$, if there is no import of these nutrients to the system in the form of purchased fodder and/or other nutrient sources. The fixation of $\mathrm{N}$ by the legumes in the forage crops appears to be insufficient as the only $\mathrm{N}$ source. The use of mineral fertilizer may very well be used to balance the flows of $\mathrm{N}, \mathrm{P}$, and $\mathrm{K}$ in mixed dairy systems, but this leads to a risk of oversupply.

A relatively fertile soil may be exposed to substantial mining of $\mathrm{N}, \mathrm{P}$, and $\mathrm{K}$ over many years without causing detectible nutrient deficits in plants cropped on this soil. A long-term over- or undersupply will, sooner or later, result in a significant change in the content of plant available nutrients in the soil, but this change may be masked by the release of nutrients from nonavailable compounds.

Field nutrient budgets appear to be a good approach to the evaluation of whether a system is managed in a balanced way or not with regard to important nutrients such as $\mathrm{N}, \mathrm{P}$, and $\mathrm{K}$, long before eventual unbalances become detectible by traditional analyses. However, the approach requires comprehensive datasets, which are usually unavailable under practical conditions.

\section{Acknowledgments}

H. Riley is gratefully acknowledged for critically reading the paper and T. Gaardløs for his skilled technical assistance. The project was funded jointly by the Norwegian Institute for Agricultural and Environmental Research, the Research Council of Norway, and Yara International ASA.

\section{References}

[1] R. Eltun, "The Apelsvoll cropping system experiment. III. Yield and grain quality of cereals," Norwegian Journal of Agriculture, vol. 10, no. 1, pp. 7-22, 1996.

[2] A. Korsaeth and R. Eltun, "Nitrogen mass balances in conventional, integrated and ecological cropping systems and the relationship between balance calculations and nitrogen runoff in an 8-year field experiment in Norway," Agriculture, Ecosystems and Environment, vol. 79, no. 2-3, pp. 199-214, 2000.

[3] G. Lien, O. Flaten, A. Korsaeth et al., "Comparison of risk in organic, integrated and conventional cropping systems in Eastern Norway," Journal of Farm Management, vol. 12, no. 7, pp. 385-401, 2006.

[4] T. A. Breland and R. Eltun, "Soil microbial biomass and mineralization of carbon and nitrogen in ecological, integrated and conventional forage and arable cropping systems," Biology and Fertility of Soils, vol. 30, no. 3, pp. 193-201, 1999.

[5] H. Riley, R. Pommeresche, R. Eltun, S. Hansen, and A. Korsaeth, "Soil structure, organic matter and earthworm activity in a comparison of cropping systems with contrasting tillage, rotations, fertilizer levels and manure use," Agriculture, Ecosystems and Environment, vol. 124, no. 3-4, pp. 275-284, 2008.
[6] A. Korsaeth, "Relations between nitrogen leaching and food productivity in organic and conventional cropping systems in a long-term field study," Agriculture, Ecosystems and Environment, vol. 127, no. 3-4, pp. 177-188, 2008.

[7] B. T. Christensen and A. E. Johnston, "Chapter 18 Soil organic matter and soil quality-Lessons learned from longterm experiments at Askov and Rothamsted," Developments in Soil Science, vol. 25, no. C, pp. 399-430, 1997.

[8] E. Ekeberg and H. Riley, "The long-term fertilizer trials at Møystad, S:E: Norway," SP Report 29, 100th Anniversary Workshop Askov Experimental Station, 1995.

[9] N. A. Fettell and H. S. Gill, "Long-term effects of tillage, stubble, and nitrogen management on properties of a redbrown earth," Australian Journal of Experimental Agriculture, vol. 35, no. 7, pp. 923-928, 1995.

[10] P. R. Poulton, "The importance of long-term trials in understanding sustainable farming systems: the Rothamsted experience," Australian Journal of Experimental Agriculture, vol. 35, no. 7, pp. 825-834, 1995.

[11] W. R. Raun, G. V. Johnson, S. B. Phillips, and R. L. Westerman, "Effect of long-term $\mathrm{N}$ fertilization on soil organic $\mathrm{C}$ and total $\mathrm{N}$ in continuous wheat under conventional tillage in Oklahoma," Soil and Tillage Research, vol. 47, no. 3-4, pp. 323330, 1998.

[12] J. Leifeld, R. Reiser, and H. R. Oberholzer, "Consequences of conventional versus organic farming on soil carbon: results from a 27-year field experiment," Agronomy Journal, vol. 101, no. 5, pp. 1204-1218, 2009.

[13] C. F. Drury, T. O. Oloya, D. J. McKenney, E. G. Gregorich, C. S. Tan, and C. L. vanLuyk, "Long-term effects of fertilization and rotation on denitrification and soil carbon," Soil Science Society of America Journal, vol. 62, no. 6, pp. 1572-1579, 1998.

[14] C. M. Penfold, M. S. Miyan, T. G. Reeves, and I. T. Grierson, "Biological farming for sustainable agricultural production," Australian Journal of Experimental Agriculture, vol. 35, no. 7, pp. 849-856, 1995.

[15] P. M. Berry, E. A. Stockdale, R. Sylvester-Bradley et al., "N, P and $\mathrm{K}$ budgets for crop rotations on nine organic farms in the UK," Soil Use and Management, vol. 19, no. 2, pp. 112-118, 2003.

[16] O. Oenema, H. Kros, and W. De Vries, "Approaches and uncertainties in nutrient budgets: implications for nutrient management and environmental policies," European Journal of Agronomy, vol. 20, no. 1-2, pp. 3-16, 2003.

[17] O. Oenema and M. Heinen, "Uncertainties in nutrient budget due to biases and errors," in Nutrient Disequilibria in Agroecosystems: Concepts and Case Studies, E. M. A. Smaling, O. Oenema, and L. O. Fresco, Eds., pp. 75-97, CAB International, Wallingford, UK, 1999.

[18] W. De Vries, J. Kros, O. Oenema, and J. De Klein, "Uncertainties in the fate of nitrogen II: a quantitative assessment of the uncertainties in major nitrogen fluxes in the Netherlands," Nutrient Cycling in Agroecosystems, vol. 66, no. 1, pp. 71-102, 2003.

[19] A. Korsaeth, "Runoff and leaching losses of N, P, and K in the period 2001-2011 in a long-term experiment with conventional and organic crop rotations," In press.

[20] WRB, World Reference Base for Soil Resources, FAO, Rome, Italy, 1998.

[21] H. Riley and R. Eltun, "The Apelsvoll cropping system experiment. II. Soil characteristics," Norwegian Journal of Agricultural Sciences, vol. 8, pp. 317-333, 1994. 
[22] H. Egnér, H. Riehm, and W. R. Domingo, "Untersuchungen über die chemische Bodenanalyse als Grundlage für die Beurteilung de Nährstoffzustandes der Böden. II," Kungliga Lantbrukshögskolans Annaler, vol. 26, pp. 199-215, 1960.

[23] W. Aas, S. Solberg, S. Manø, and K. E. Yttrei, "Overvåking av langtransportert forurenset luft og nedbør," Report NILU OR 22/2007, Kjeller, Norway, 2007.

[24] IPCC National Greenhouse Gas Inventories Programme, "Agriculture, forestry and other land use," in IPCC Guidelines for National Greenhouse Gas Inventories, H. S. Eggleston, L. Buendia, K. Miwa, T. Ngara, and K. Tanabe, Eds., vol. 4, chapter 11, pp. 1-11, IGES, Japan, 2006.

[25] L. Larsson, M. Ferm, Å. Kasimir-Klemedtsson, and L. Klemedtsson, "Ammonia and nitrous oxide emissions from grass and alfalfa mulches," Nutrient Cycling in Agroecosystems, vol. 51, no. 1, pp. 41-46, 1998.

[26] K. A. Gomez and A. A. Gomez, Statistical Procedures for Agricultural Research, Wiley \& Sons, New York, NY, USA, 2nd edition, 1984.

[27] H. Riley and E. Ekeberg, "Effects of depth and time of ploughing on yields of spring cereals and potatoes and on soil properties of a morainic loam soil," Acta Agriculturae Scandinavica - Section B Soil and Plant Science, vol. 48, no. 4, pp. 193-200, 1998.

[28] R. Eltun, A. Korsaeth, and O. Nordheim, "A comparison of environmental, soil fertility, yield, and economical effects in six cropping systems based on an 8-year experiment in Norway," Agriculture, Ecosystems and Environment, vol. 90, no. 2, pp. 155-168, 2002.

[29] L. Bergström, H. Kirchmann, H. Aronsson, G. Torstensson, and L. Mattsson, "Use Efficiency and Leaching of Nutrients in Organic and Conventional Cropping Systems in Sweden," in Organic Crop Production-Ambitions and Limitations, $\mathrm{H}$. Kirchmann and L. Bergström, Eds., pp. 117-141, Springer, New York, NY, USA, 2008.

[30] H. Riley and M. Bakkegard, "Declines of soil organic matter content under arable cropping in southeast Norway," Acta Agriculturae Scandinavica Section B, vol. 56, no. 3, pp. 217223, 2006.

[31] G. Torstensson, H. Aronsson, and L. Bergstrom, "Nutrient use efficiencies and leaching of organic and conventional cropping systems in Sweden," Agronomy Journal, vol. 98, no. 3, pp. 603615, 2006.

[32] D. P. Heenan, W. J. McGhie, F. M. Thomson, and K. Y. Chan, "Decline in soil organic carbon and total nitrogen in relation to tillage, stubble management, and rotation," Australian Journal of Experimental Agriculture, vol. 35, no. 7, pp. 877-884, 1995.

[33] G. Uhlen, "Long-term effects of fertilizers, manure, straw and crop rotation on total-N and total-C in soil," Acta Agriculturae Scandinavica, Section B, vol. 41, pp. 119-127, 1991.

[34] H. Steinshamn, E. Thuen, M. A. Bleken, U. T. Brenoe, G. Ekerholt, and C. Yri, "Utilization of nitrogen $(\mathrm{N})$ and phosphorus (P) in an organic dairy farming system in Norway," Agriculture, Ecosystems and Environment, vol. 104, no. 3, pp. 509-522, 2004.

[35] E. Syväsalo, K. Regina, E. Turtola, R. Lemola, and M. Esala, "Fluxes of nitrous oxide and methane, and nitrogen leaching from organically and conventionally cultivated sandy soil in western Finland," Agriculture, Ecosystems and Environment, vol. 113, no. 1-4, pp. 342-348, 2006.

[36] D. J. Greenwood, F. Gastal, G. Lemaire, A. Draycott, P. Millard, and J. J. Neeteson, "Growth rate and \% N of field grown crops: theory and experiments," Annals of Botany, vol. 67, no. 2, pp. 181-190, 1991.

[37] F. E. Khasawneh and E. C. Doll, "The use of phosphate rock for direct application to soils," Advances in Agronomy, vol. 30, no. C, pp. 159-206, 1979.

[38] M. Odlare, M. Pell, and K. Svensson, "Changes in soil chemical and microbiological properties during 4 years of application of various organic residues," Waste Management, vol. 28, no. 7, pp. 1246-1253, 2008.

[39] H. Bengtsson, I. Öborn, S. Jonsson, I. Nilsson, and A. Andersson, "Field balances of some mineral nutrients and trace elements in organic and conventional dairy farming-a case study at Örjebyn, Sweden," European Journal of Agronomy, vol. 20, no. 1-2, pp. 101-116, 2003.

[40] J. Verloop, J. Oenema, S. L. G. Burgers, H. F. M. Aarts, and $\mathrm{H}$. van Keulen, "P-equilibrium fertilization in an intensive dairy farming system: effects on soil-P status, crop yield and P leaching," Nutrient Cycling in Agroecosystems, vol. 87, no. 3, pp. 369-382, 2010.

[41] H. Riley, "Long-term fertilizer trials on loam soil at Møystad, south-eastern Norway: crop yields, nutrient balances and soil chemical analyses from 1983 to 2003," Acta Agriculturae Scandinavica Section B, vol. 57, no. 2, pp. 140-154, 2007.

[42] L. Taiz and E. Zeiger, Plant Physiology, Sinauer Associates, Sunderland, Mass, USA, 3rd edition, 2002.

[43] S. Mathews, J. P. I. Tritschler, and S. C. Miyasaka, "Phosphorus management and sustainability," in Grass for Daily Cattle, J. H. Cherney and D. J. R. Cherney, Eds., pp. 193-222, CABI International, Wallingford, UK, 1998.

[44] S. D. Heming, "Potassium balances for arable soils in southern England 1986-1999," Soil Use and Management, vol. 20, no. 4, pp. 410-417, 2004.

[45] L. Blake, S. Mercik, M. Koerschens et al., "Potassium content in soil, uptake in plants and the potassium balance in three European long-term field experiments," Plant and Soil, vol. 216, no. 1-2, pp. 1-14, 1999.

[46] I. Öborn, Y. Andrist-Rangel, M. Askekaard, C. A. Grant, C. A. Watson, and A. C. Edwards, "Critical aspects of potassium management in agricultural systems," Soil Use and Management, vol. 21, pp. 102-112, 2005.

[47] A. F. Øgaard and S. Hansen, "Potassium uptake and requirement in organic grassland farming," Nutrient Cycling in Agroecosystems, vol. 87, no. 1, pp. 137-149, 2010.

[48] Y. Andrist-Rangel, A. C. Edwards, S. Hillier, and I. Öborn, "Long-term $\mathrm{K}$ dynamics in organic and conventional mixed cropping systems as related to management and soil properties," Agriculture, Ecosystems and Environment, vol. 122, no. 4, pp. 413-426, 2007.

[49] J. Holmqvist, A. F. Øgaard, I. Öborn, A. C. Edwards, L. Mattsson, and H. Sverdrup, "Application of the Profile model to estimate potassium release from mineral weathering in Northern European agricultural soils," European Journal of Agronomy, vol. 20, no. 1-2, pp. 149-163, 2003.

[50] H. Kuhlmann, "Importance of the subsoil for the K nutrition of crops," Plant and Soil, vol. 127, no. 1, pp. 129-136, 1990.

[51] L. E. De-Bashan and Y. Bashan, "Recent advances in removing phosphorus from wastewater and its future use as fertilizer (1997-2003)," Water Research, vol. 38, no. 19, pp. 4222-4246, 2004.

[52] A.-G. Roer, A. Korsaeth, T. M. Henriksen, O. Michelsen, and A. H. Strømman, "The influence of system boundaries on life cycle assessment of grain production in central southeast Norway," Agricultural Systems, vol. 111, pp. 75-84, 2012. 

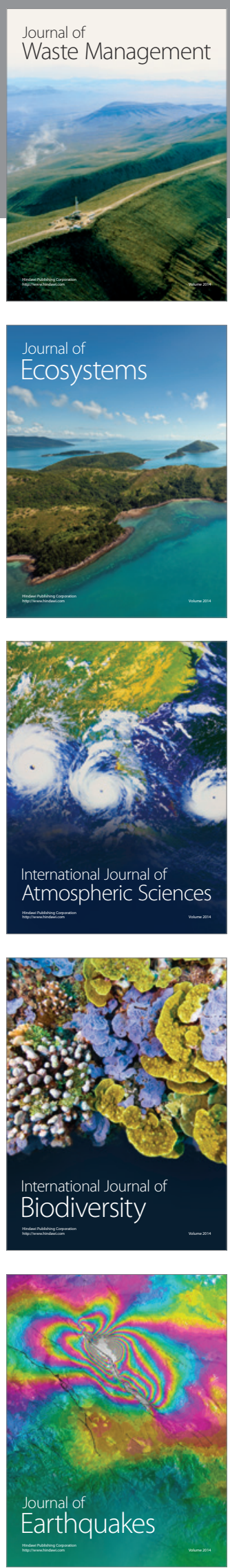
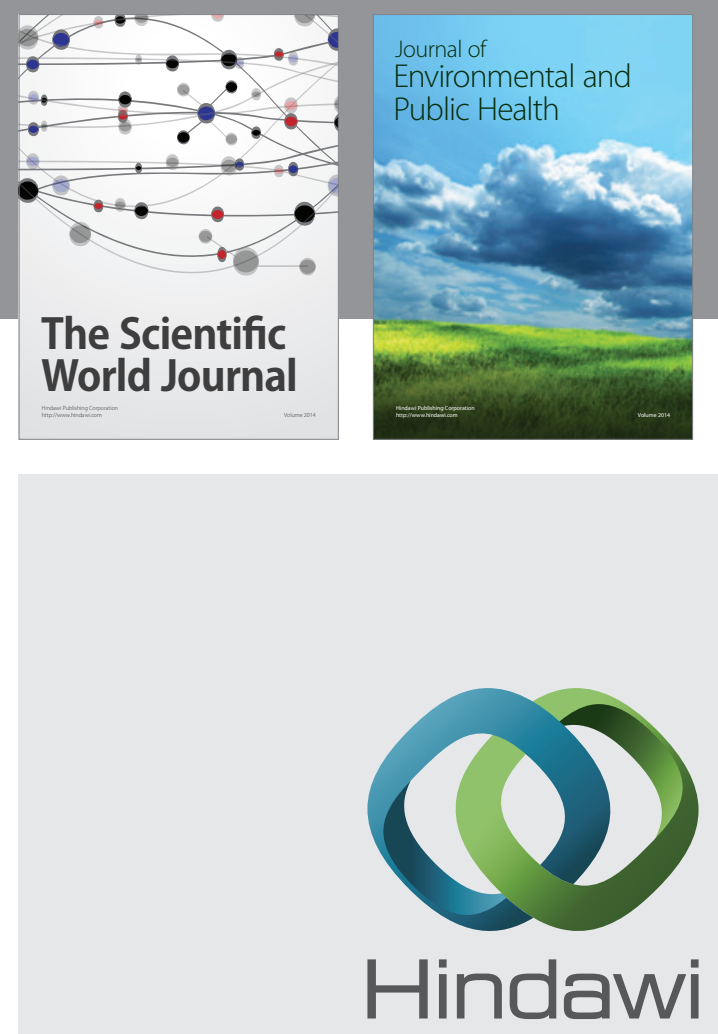

Submit your manuscripts at

http://www.hindawi.com
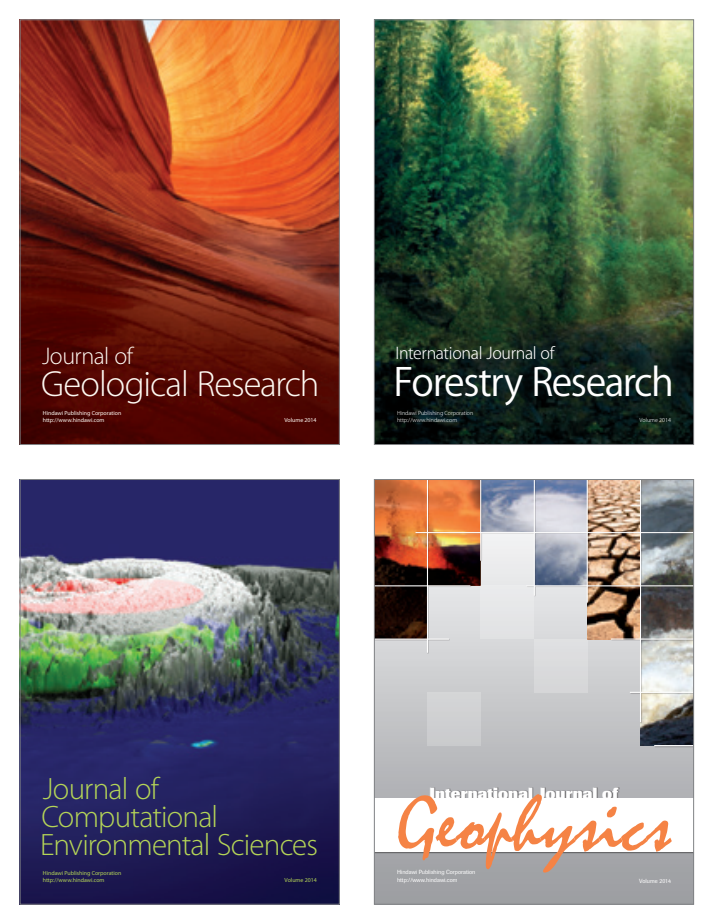
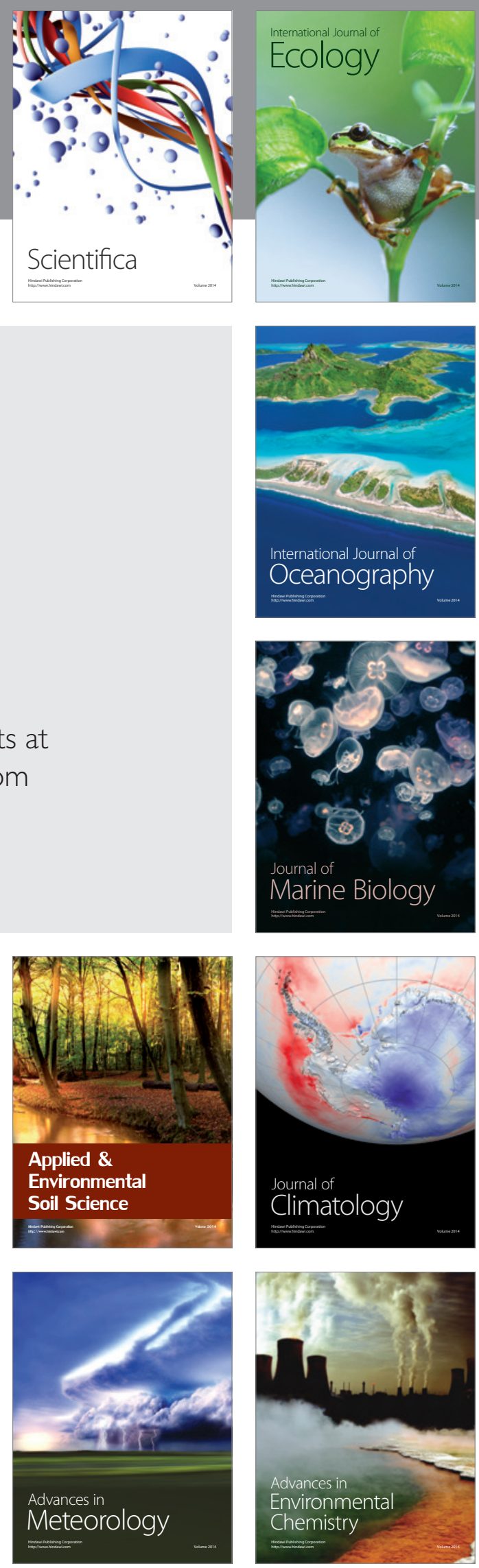